\title{
ARTICLE
}

\section{TORTURE, IMPUNITY, AND THE NEED FOR INDEPENDENT PROSECUTORIAL OVERSIGHT OF THE EXECUTIVE BRANCH}

\author{
Fran Quigley*
}

Allegations of Executive Branch misconduct present an inherent conflict of interest because prosecutorial discretion is invested in a U.S. Attorney General appointed by-and serving at the pleasure of-the President. Various commentators, including Justice Antonin Scalia, Professor Stephen Carter, and the many critics of the former independent counsel statute have posited that checks on executive power provided by the Legislative Branch, the Judiciary, and political pressure will overcome any potential conflicts of interest.

This sanguine view of adequate Executive Branch oversight was put to the test when high-level members of the George W. Bush Administration authorized acts of torture. After widespread public disapproval, Congress and the courts responded with efforts to rein in the Administration's actions. However, the Department of Justice under the Bush Administration not only refused to investigate and prosecute allegations of sanctioning torture, but its attorneys also led the efforts to overcome congressional, judicial, and popular resistance to the Executive Branch conduct-and did so while explicitly acknowledging that the Executive Branch could expect little or no judicial oversight for its actions. Ultimately, the President who sanctioned torture left office, and the voters elected a President who expressed sharply different views on torture. However, the subsequent Administration of President Barack Obama, although affiliated with a different party and on record as opposed to acts of torture sponsored by the previous Administration, has also declined to pursue prosecution of high-level members of the Bush Administration.

This most recent development shows that the conflict of interest presented by presidential control over Executive Branch prosecution

* Visiting Professor, Indiana University School of Law-Indianapolis; Associate Director, Indiana-Kenya Partnership/AMPATH; Staff Attorney, Indiana Legal Services. The Author thanks Florence Wagman Roisman and Bill Quigley for their review and comments on earlier versions of this Article, the staff of the Cornell Journal of Law and Public Policy for their careful and thorough editing of this Article, and Andrea Ciobanu for her research assistance. 
transcends predictable concerns of self-preservation. The conflict of interest also highlights the natural desire of a sitting President to avoid prosecutions of previous executive officials when such prosecutions would consume political capital needed for the President's broader legislative and foreign policy agendas. When it comes to controlling Executive Branch criminal conduct, the current structure designed to provide checks and balances comes up empty and thus must be reformed. The most direct and effective reform would be the direct election of the U.S. Attorney General. Even less precise remedies, such as a revived and improved independent counsel or Congress enacting provisions to break up the current monopoly over Executive Branch prosecution, would be significant improvements over the current system, which mocks the principle of equal justice for all.

INTRODUCTION

I. U.S. Executive Branch IMPUNity Under aN "INHouse" AtTorney General .................... 273

A. The Bush Administration and Torture ........... 273

B. The Sanguine View of Prosecutorial Conflict of Interest Assessed in the Context of Torture ......... 280

C. The Realities of Unchecked Executive Power ....... 282

D. A New President; Continued Impunity for Torture ... 284

II. The Missing Legal and Historical Foundations for President-Controlled Federal Prosecutions ........ 289

A. The English and Colonial Traditions ............. 289

B. The Constitutional Convention and the First Congress ............................... 289

C. Post-Founding Evolution of the U.S. Attorney General

III. More Prosecutorial Independence Would Lead to Better Governance .......................... 293

A. Empirical Evidence That Executive Control over Prosecution Increases Chances of Corruption....... 293

B. Empirical Evidence That an Unbundled Executive Provides More Effective Governance ............. 294

IV. Options for Independent Prosecutorial Oversight of the Executive Branch......................... 296

A. Direct Election of a Federal Attorney General...... 296

B. A Revived-and Revised-Independent Counsel ..... 299

1. History of the Independent Counsel .......... 299

2. The Special Counsel ................... 302

3. Envisioning a Revived and Redesigned Independent Counsel .................... 303 
C. Breaking up the Prosecutorial Monopoly: Alternatives for Pursuing Executive Branch Misconduct

1. Victim-Initiated Actions Against Executive Branch Officials ......................... 305

2. Pursuit of Ethical Complaints Against Attorneys General and Department of Justice Officials .... 307

3. Greater Investigative Power for Congress or an Inspector General ....................... 308

4. Non-federal Prosecution of Executive Branch Crimes ............................... 309

Conclusion......................................... 311

\section{INTRODUCTION}

The control that the President of the United States holds over the appointment and removal of the Attorney General, who is entrusted with prosecutorial oversight over the President and his top appointees, presents a clear conflict of interest and calls into question the claim that no U.S. officeholder is above the law. Under two very different presidential administrations, Bush Administration officials have enjoyed impunity for sanctioning acts of torture. This fact debunks the argument that countervailing interests and powers in the Legislative and Judicial Branches of government, and the political process, reduce the conflict of interest inherent in presidential control over the Attorney General.

Part I of this Article evaluates the sanguine view of the federal prosecutorial conflict of interest in the context of the Bush Administration's sanctioning of torture. Part II reviews the historical and legal basis for an attorney general beholden to the President and uncovers the fact that the founders were not at all wedded to the idea of President-controlled federal law enforcement. Part III discusses the empirical evidence demonstrating that more prosecutorial independence would lead to better governance and less corruption. Part IV analyzes different options for reform, particularly (1) direct election of the Attorney General, (2) revival of an independent counsel position that remedies the flaws of the Independence Counsel Act, and (3) various proposals for breaking up the Attorney General's monopoly on prosecutions of the Executive Branch.

\section{U.S. Executive Branch Impunity Under an "IN-House" ATtORney General}

\section{A. The Bush Administration and Torture}

By 2008, members of President George W. Bush's Administration had been implicated in so many alleged criminal activities that a popular 
news website, Slate, created a multi-color, interactive graphic to chart possible criminal charges against high-level Executive Branch officials for activities such as approving torture, illegally wiretapping U.S. citizens, and politicizing Department of Justice hirings and firings. ${ }^{1}$ The existence of such an array of possible criminal activity by a two-term administration is less remarkable than the fact that, in a country that prides itself in being a nation "of laws and not men," 2 none of these accusations had led to the prosecution of a single high-level Executive Branch official. ${ }^{3}$

A particularly notorious example of unprosecuted criminal activity in the Bush Executive Branch was the explicit and repeated authorization for agents of the Central Intelligence Agency to physically and psychologically abuse al-Qaeda suspects. During the Bush Administration, the Department of Justice officially approved the following acts:

- Slamming suspects into walls,

- Slapping and grabbing suspects,

- Placing detainees in "confinement boxes" for up to eighteen hours,

- Placing insects in the confinement boxes with detainees,

- Compelling detainees to remain in "stress positions" for unspecified amounts of time,

- Depriving detainees of sleep for as many as eleven days at a time, and

- Waterboarding, which produces the sensation of drowning and suffocation. ${ }^{4}$

1 See Emily Bazelon et al., Crimes and Misdemeanors, SLATE (July 24, 2008, 6:55 AM), http://www.slate.com/id/2195892/.

2 See, e.g., MAss. Const. pt. 1, art. XXX. John Adams authored the famous statement of the rule of law. See John Adams and the Massachusetts Constitution, Sup. JuD. CT., http:// www.mass.gov/courts/sjc/john-adams-b.html (last visited Nov. 26, 2010).

3 See Mark Thompson, Obama's Growing Dilemma on Torture Prosecution, Time, Apr. 22, 2009, http://www.time.com/time/politics/article/0,8599,1893023,00.html. A special prosecutor was appointed to investigate the destruction of evidence of CIA interrogations during the Bush Administration, but no charges have yet been filed. See Mark Mazetti, Grand Jury Inquiry on Destruction of C.I.A. Tapes, N.Y. Times, July 2, 2009, at A14.

4 Cent. Intelligence Agency, Office of InSPector Gen., Special Review: Counterterrorism Detention and Interrogation Activities (Sept. 2001-Oct. 2003) 21 (2004), available at http://luxmedia.com.edgesuite.net/aclu/IG_Report.pdf [hereinafter CIA OIG REP.]. Waterboarding is described as follows:

[T] he individual is bound securely to an inclined bench... . A cloth is placed over the forehead and eyes. Water is then applied to the cloth in a controlled manner. As this is done, the cloth is lowered until it covers both the nose and mouth. Once the cloth is saturated and completely covers the mouth and nose, the air flow is slightly restricted for 20 to 40 seconds due to the presence of the cloth. ... [A]n increase in the carbon dioxide level stimulates [an] increased effort to breathe. This effort plus the cloth produces the perception of "suffocation and incipient panic," i.e., the perception of drowning. . . . During those 20 to 40 seconds, water is continuously ap- 
According to a heavily redacted 2004 report from the Central Intelligence Agency Office of the Inspector General, ${ }^{5}$ made public in 2009, the Department of Justice issued these guidelines, and CIA agents followed them. ${ }^{6}$ According to the report, CIA agents used the waterboarding technique on one suspect 183 times in a single month ${ }^{7}$ and on another suspect eighty-three times in a single month. ${ }^{8}$ They used larger volumes of water than prescribed while attempting to block the detainees' air flow. ${ }^{9}$ In addition, detainees were threatened with a power drill and handgun, ${ }^{10}$ told that their daughters and mothers would be sexually abused in front of them, ${ }^{11}$ and that their children would be killed if another attack occurred on the United States after 9/11.12 CIA agents also choked detainees, ${ }^{13}$ subjected them to mock executions, ${ }^{14}$ left them in extreme cold while shackled and naked, ${ }^{15}$ and beat them with rifle butts and large metal flashlights. ${ }^{16}$ CIA officials subsequently briefed senior Bush Administration officials on the Agency's use of "enhanced interrogation techniques," and the CIA officials reassured Bush Administration officials that the Department of Justice approved the conduct. ${ }^{17}$

plied from a height of [12 to 24] inches. After this period, the cloth is lifted, and the individual is allowed to breathe unimpeded for three or four full breaths. . . The procedure may then be repeated. ... [T] This procedure triggers an automatic physiological sensation of drowning that the individual cannot control ... [I]t is likely that this procedure would not last more than 20 minutes in any one application.

Id.

5 The Inspector General of the CIA is a position created by Congress to conduct independent investigations, inspections and audits, and report accordingly to both the CIA director and the Senate Select Committee on Intelligence and the House Permanent Select Committee on Intelligence. The Inspector General is statutorily mandated to provide both semi-annual reports and immediate reports of "serious or flagrant problems" within the Agency. See 50 U.S.C. $\S 403 q(d)(2)(2006)$.

6 CIA OIG REP., supra note 4, at 24.

7 Id. at 91 .

8 Id. at 36.

9 Id. at 37 (stating that the "waterboard technique employed ... was different from the technique as described in the DoJ opinion and used in the SERE training").

10 Id. at 41-42 (classifying the use of the Handgun and Power Drill under the list of "Specific Unauthorized or Undocumented Techniques").

11 CIA OIG REP., supra note 4, at 42-43.

12 Id. at 43 .

13 Id. at 69.

14 Id. at 70 .

$15 \mathrm{Id}$. at 75 .

16 Id. at 79. U.S. military personnel at Guantanamo Naval Base used similar techniques against detainees including stripping detainees naked, threatening them with dogs, depriving them of sleep, and making detainees wear dog leashes and perform dog tricks. See STAFF of S. Comm. on Armed Servs., 110 th Cong., Inquiry into the Treatment of Detainees in U.S. CusTody xxi (2008), available at http://levin.senate.gov/newsroom/supporting/2008/Detainees.121108.pdf [hereinafter Armed Servs., Detainee Treatment].

17 See CIA OIG REP., supra note 4, at 101. 
In order to back up this informal reassurance, the Department of Justice issued six formal memoranda between August of 2002 and December of 2005.18 In each memorandum, the Department concluded that the CIA's proposed or existing interrogation techniques were fully lawful ${ }^{19}$ and, in the process, ignored well-settled definitions of what constitutes the illegal act of torture. ${ }^{20}$ Furthermore, Executive Branch officials, including cabinet members and the President himself, approved and endorsed these techniques. ${ }^{21}$ As the Senate Armed Services Committee later concluded:

The abuse of detainees in U.S. custody cannot simply be attributed to the actions of "a few bad apples" acting on their own. The fact is that senior officials in the United States government solicited information on how to use aggressive techniques, redefined the law to create the ap-

18 See The Torture Memos: Rationalzzing the Unthinkable 3 (David Cole ed., 2009) [Hereinafter TORTURE MEMOs].

19 See id. at 4.

20 See, e.g., Memorandum from Jay Bybee, Assistant Attorney Gen., U.S. Dep't of Justice, Office of Legal Counsel, to Alberto R. Gonzales, Counsel to the President, Re: Standards of Conduct for Interrogation Under 18 U.S.C. 2340-2340A (Aug. 1, 2002) [hereinafter Bybee Memo], in TORTURe Memos, supra note 18, at 41 (concluding that an act is not torture unless the pain inflicted is "equivalent in intensity to the pain accompanying serious physical injury, such as organ failure, impairment of bodily function, or even death"). This definition was not in line with established domestic and international definitions of the term. See supra note 16; see also Mike Allen \& Dana Priest, Memo on Torture Draws Focus to Bush, WAsh. Post, June 9, 2004, at A04 (noting that the DoJ definition of torture differed from the Army's definition of torture). Moreover, Jack Goldsmith, a subsequent Assistant Attorney General in the Office of Legal Counsel, repudiated the definition two years later. See Jeffrey Rosen, Conscience of a Conservative, N.Y. TimEs MAG., Sept. 9, 2007, at 42. Among the reams of precedent ignored in the August 2002 memo was the fact that the act of waterboarding alone had resulted in multiple criminal convictions of local and foreign defendants in U.S. tribunals. See Scott Horton, Justice After Bush: Prosecuting an Outlaw Administration, HARPER's, Dec. 2008 , at 49 .

21 See Jan Crawford Greenburg et al., Bush Aware of Advisers' Interrogation Talks, ABC News (Apr. 11, 2008), http://abcnews.go.com/TheLaw/LawPolitics/story?id=4635175\& page $=1$ \&page $=1$ (quoting President Bush as saying in reference to "enhanced interrogation techniques": "Well, we started to connect the dots in order to protect the American people. And yes, I'm aware our national security team met on this issue. And I approved."). Specifically, President Bush's February 7, 2002 memorandum stated that the Third Geneva Convention did not apply to the conflict with al Qaeda, and that Taliban detainees were not entitled to prisoner of war status or the legal protections provided by the Third Geneva Conventions "opened the door" to subsequent mistreatment of prisoners. See Armed Servs., Detainee Treatment, supra note 16, at xiii. Members of the President's cabinet and other senior officials, including Secretary of Defense Donald Rumsfeld, Attorney General John Ashcroft, Director of Central Intelligence George Tenet and then-National Security Advisor Condoleezza Rice were personally involved in the review and approval of the interrogation techniques. See id. at xv, xix, xxvi; see also Dan Eggen, Cheney's Remarks Fuel Torture Debate, WASH. Post, Oct. 27, 2006, at A9 (citing Vice President Dick Cheney's statement that approving waterboarding was a "no-brainer for me"); Jan Crawford Greenburg et al., supra. 


\author{
pearance of their legality, and authorized their use \\ against detainees. ${ }^{22}$
}

These acts of torture are contrary to express provisions of U.S. law that prohibit "cruel, inhuman, and degrading treatment" of detainees. ${ }^{23}$ As has been outlined in great detail elsewhere, ${ }^{24}$ these acts of torture and the sanctioning of torture also violate Common Article 3 of the Geneva Conventions, ${ }^{25}$ the Convention Against Torture, ${ }^{26}$ Article 7 of the Inter-

22 Armed Servs., Detainee Treatment, supra note 16, at xii.

23 See, e.g., Detainee Treatment Act of 2005, 42 U.S.C. $\$ 2000 \mathrm{dd}$ (2005).

24 See, e.g., ToRTuRE MEMOs, supra note 18, at 6-40; Daniel Kanstroom, On "Waterboarding": Legal Interpretation and the Continuing Struggle for Human Rights, 32 B.C. INT'L \& Comp. L. Rev. 203, 210-11 \& n.37 (2009); Seth F. Kreimer, Torture Lite, "Full Bodied" Torture, and the Insulation of Legal Conscience, 1 J. NAT'L Security L. \& PoL'y 187, 201-25 (2005); Jordan J. Paust, Executive Plans and Authorizations to Violate International Law Concerning Treatment and Interrogation of Detainees, 43 Colum. J. TransNat'L L. 811, 838-62 (2005) [hereinafter Paust, Executive Plans]; Phillipe Sands, Torture Team: Abuse, Lawyers, And Criminal Responsibility, 48 WAShBuRN L.J. 353, 356-57 (2009); Bob Woodward, Detainee Tortured, Says U.S. Official: Trial Overseer Cites "Abusive" Methods Against 9/11 Suspect, WASH. Post, Jan. 14, 2009, at A1 (quoting Susan J. Crawford, convening authority of military commissions to the U.S. military, who concludes that the United States tortured Saudi national Mohammed al-Qahtani at Guantanamo); Owen Fiss, The Example of America, Yale L.J. Pocket PART 4-5 (May 1, 2009), available at http://yalelawjournal.org/images/pdfs/764.pdf.

25 Geneva Convention Relative to the Protection of Civilian Persons in Times of War, art. 3, Aug. 12, 1949, 6 U.S.T. 3516, 75 U.N.T.S. 287; Geneva Convention Relative to the Treatment of Prisoners of War, art. 3, Aug. 12, 1949, 6 U.S.T. 3316, 75 U.N.T.S. 135. Ratified unanimously by the Senate in 1955, the common Article 3 prohibits parties to the treaty from committing certain acts upon prisoners, including "violence to life and person, in particular murder of all kinds, mutilation, cruel treatment, and torture . . outrages upon personal dignity, in particular, humiliating and degrading treatment." Geneva Convention Relative to the Protection of Civilian Persons in Times of War, art. 3, Aug. 12, 1949, 6 U.S.T. 3516, 75 U.N.T.S. 287; Geneva Convention Relative to the Treatment of Prisoners of War, art. 3, Aug. 12, 1949, 6 U.S.T. 3316, 75 U.N.T.S. 135.

26 Convention Against Torture and Other Cruel, Inhuman or Degrading Treatment or Punishment, art. 2(1), Dec. 10, 1984, 1465 U.N.T.S. 85 [Hereinafter Convention Against Torture]. The Convention states that each party to the treaty "shall take effective legislative, administrative, judicial or other measures" to prevent acts of torture or other acts of cruel, inhuman, or degrading treatment or punishment in any territory under its jurisdiction. See id. In other words, the United States has accepted an affirmative obligation to investigate and, where appropriate, prosecute acts of torture; see also 136 CONG. REC. S 17,491 (daily ed. Oct. 27, 1990) (statement of Sen. Kassebaum) ("The Torture Convention . . . [W]ould send a powerful signal to torturers around the world that the United States will not tolerate its practice."). The Supreme Court has ruled that intentional infliction of physical or emotional harm in order to obtain information from a detainee "shocks the conscience" and thus violates the Due Process Clause. See Chavez v. Martinez, 538 U.S. 760, 774-75 (1994). The May 30, 2005 memorandum from the Department of Justice to John A. Rizzo, Senior Deputy General Counsel, CIA, acknowledges that the "shocks the conscience" standard governs the legality of interrogation methods. See Memorandum from Stephen J. Bradbury, Principal Deputy Assistant Atty. Gen., U.S. Dep't. of Justice, Office of Legal Counsel, to John A. Rizzo, Senior Deputy General Counsel, C.I.A., Re: Application of United States Obligations Under Article 16 of the Convention Against Torture to Certain Techniques That May Be Used in the Interrogation of High Value al-Qaeda Detainees (May 30, 2005) [hereinafter Bradbury Memorandum], in TORTuRe MeMos, supra note 18, at 227-28. 
national Covenant on Civil and Political Rights, ${ }^{27}$ and Article 5 of the Universal Declaration of Human Rights, ${ }^{28}$ each of which the U.S. has ratified. Further, the Geneva Conventions and the Convention Against Torture expressly require the United States and other parties to the treaties to investigate allegations of human rights violations and prosecute the offenders. ${ }^{29}$ As Professor Jordan Paust writes, "Never in the long history of the United States has there been such widespread serial criminality authorized and abetted at the highest levels of our government." 30

The lack of prosecution for crimes like these may surprise students of U.S. civics that are taught that even powerful officeholders are not above the law. ${ }^{31}$ But students of human nature, not to mention those of rational choice theory (which depicts human beings as largely maximizers of their own self-interest), ${ }^{32}$ might expect an absence of criminal charges, given the powerful self-interests working against prosecution. The United States grants the Attorney General a monopoly on the power to prosecute Executive Branch officials but simultaneously requires him

27 International Covenant on Civil and Political Rights, art. 7, Dec. 16, 1966, 999 U.N.T.S. 171, 173 (entered into force Mar. 23, 1976), ratified by U.S. Senate Resolution of Advice and Consent to Ratification of the International Covenant on Civil and Political Rights, 102d Cong. (1992) (enacted), 138 Cong. ReC. 8070 (daily ed. Apr. 2, 1992). The U.S. Senate ratified this treaty subject to reservations that the prohibited activities were the equivalent of those already prohibited under the Fifth, Eight and Fourteenth Amendments to the U.S. Constitution. See id.; see also 138 Cong. Rec. S4,783 (daily ed. Apr. 2, 1992) (statement of Sen. Moynihan) (noting that the Covenant "reflects the principles articulated in our own Bill of Rights").

28 G.A. Res. 217A, at 73, U.N. GAOR, 3d Sess., 183d plen. mtg., U.N. Doc. A/810 (Dec. 10,1948 ) ("No one shall be subjected to torture or to cruel, inhuman or degrading treatment or punishment.").

29 See Convention Against Torture, supra note 26, at art. 6; Geneva Convention Relative to the Protection of Civilian Persons in Time of War, art. 146, Aug, 12, 1949, 6 U.S.T. 3516, 75 U.N.T.S. 973.

30 Jordan J. Paust, The Absolute Prohibition of Torture and Necessary and Appropriate Sanctions, 43 VAL. U. L. Rev. 1535, 1575 (2009) [hereinafter Paust, Absolute Prohibition].

31 See, e.g., Marbury v. Madison, 5 U.S. 137, 163 (1803) ("The Government of the United States has been emphatically termed a government of laws, and not of men."). States often require students to study Marbury. See, e.g., Colo. Model Content Standards: CivICs 12-13 (2008), available at http://www.cde.state.co.us/cdeassess/documents/OSA/standards/civics.pdf (recommending that high school students learn about Marbury in connection with separation of powers and judicial review); Georgia Dep't of Educ., Social Studies, AMERICAN GoverNMENT/Civics, STANDARDs 3 (2004), available at https://www.georgiastandards.org/standards/Georgia\%20Performance\%20Standards/American\%20Government $\% 2020$ 09-2010\%208-14-2008.pdf (stating that students are taught Marbury in the context of learning how the decision "established the Supreme Court as an independent, coequal branch of government").

32 See, e.g., Gary Becker, The Economic Approach to Human Behavior 5-14 (1976). 
to oversee the Department of Justice, ${ }^{33}$ whose Office of Legal Counsel ${ }^{34}$ was at the core of the torture crimes. ${ }^{35}$ Complicating this conflict, the Attorney General serves at the pleasure of a President who controls the entire Executive Branch of government. ${ }^{36}$

Thus, under the U.S. Constitution and current statutory scheme, the ironies-and the conflicts-abound. Despite being labeled "America's lawyer"37 and subject to ethical rules prohibiting her from showing favoritism in any prosecution decision, ${ }^{38}$ the Attorney General has the closest possible organizational ties to a potential target of prosecution by serving as a member of the President's cabinet and overseeing an Executive Branch department. ${ }^{39}$ Although the Office of Legal Counsel has been described as the "constitutional conscience" of the Department of Justice, ${ }^{40}$ it was that very office that repeatedly approved systemic acts of torture in contradiction to clear legal mandates. ${ }^{41}$ While Alberto Gonza-

33 See Judiciary Act of 1789, ch. 20, 1 Stat. 73, 92-93 (establishing the office of Attorney General and granting the Attorney General prosecution power); see also Act of June 22, 1870 , ch. 150,16 Stat. 162,162 (codified at 5 U.S.C. $\$ 311$ (1926)) ("[T]here shall be, and is hereby, established an executive department of the United States, to be called the Department of Justice, of which the Attorney General shall be the head."); 28 U.S.C. $\$ 503$ (2006) ("The Attorney General is the head of the Department of Justice.").

34 OLC lawyers are said to "represent the long-term institutional interests of the executive branch, and are supposed to exercise judgment independent of the political will of the [P]resident." TORTURE MEmos, supra note 18, at 11 (citation omitted). The office has historically attracted some of America's most distinguished legal minds, such as Antonin Scalia, Walter Dellinger, and Harold Koh. See id.

35 See id. at 13-19.

36 See Humphrey's Executor v. United States, 295 U.S. 602, 629 (1935) (holding that the President can only remove quasi-legislative and quasi-judicial officers with the consent of Congress); Myers v. United States, 272 U.S. 52, 122 (1926) (holding that the President has the exclusive power to remove Executive Branch officials and does not need the approval of the Senate or any other legislative body). The Bush Administration exercised a historically high level of control over U.S. Attorneys and fired nine U.S. Attorneys in the middle of George W. Bush's second term for what many concluded were partisan reasons. See generally David C. Weiss, Note, Nothing Improper? Examining Constitutional Limits, Congressional Action, Partisan Motivation, and Pretextual Justification in the United States Attorney Removal, 107 Mich. L. REv. 317 (2008) (arguing that Congress should consider legislation limiting the ability of the President to remove U.S. Attorneys).

37 Press Release, Sen. Herbert Kohl, Nomination of John Ashcroft to be Attomey General of the United States (Jan. 30, 2001) (on file with author) ("Not only must the President trust his Attorney General, the nation must also trust him, for, after all, the Attorney General is America's lawyer.").

38 See, e.g., Diana N. Viggiano, Note, Aiming the Canons at the General: How Should Traditional Canons of Legal Ethics Guide and Constrain an Attorney General?, 22 GEo. J. Legal ETHICS 1193, 1198-99 (2009).

39 See 5 U.S.C. $\$ 311$ (1926); 28 U.S.C. $\$ 503$ (2006).

40 David Cole, The Torture Memos: The Case Against the Lawyers, N.Y. REv. Books, Oct. 8, 2009, at 15, available at http://www.nybooks.com/articles/archives/2009/oct/08/thetorture-memos-the-case-against-the-lawyers/.

41 See Torture Memos, supra note 18, at 3-4. Harold Hongju Koh, former Dean of Yale Law School and former Assistant Attorney General in the Office of Legal Counsel, in testimony before the Senate Judiciary Committee, stated, "[I]n my professional opinion . . . the 
les was described as "America's top cop" during the two and a half years he served as Attorney General in the Bush Administration, ${ }^{42}$ he was also personally connected to most of the crimes allegedly committed by Bush Administration officials. ${ }^{43}$ As the Slate interactive chart notes in the introduction to its diagram of Bush Administration misconduct, "[I]f all else fails, fall back on the golden rule of wrongdoing in the [Bush] White House: All roads lead to Gonzales." 44

Anyone capable of grasping the intuitive dysfunction of the fox guarding the henhouse, or familiar with the fate of Thomas More after he dared to defy Henry VIII's wishes, can understand the problem of granting prosecutorial power to a U.S. official under the President's control. ${ }^{45}$ The flawed U.S. system allows the most powerful officeholder in the land to choose, supervise, and terminate at will the sole law enforcement officer who has authority to initiate criminal proceedings against the Executive and his other appointees. ${ }^{46}$

\section{B. The Sanguine View of Prosecutorial Conflict of Interest Assessed in the Context of Torture}

This glaring conflict of prosecutorial interest appears too obvious to deny, but some prominent constitutional scholars have defended the status quo by reassuring us that the nation's systems of checks and balances will remedy the problem. These scholars often take as their starting point the 1988 Supreme Court case of Morrison v. Olson. ${ }^{47}$ In Morrison, the Supreme Court upheld the constitutionality of the Independent Counsel Act, ${ }^{48}$ which established an independent prosecutor to investigate misconduct by the President and other federal officials. ${ }^{49}$ The majority opinion was not without its critics, however-the most prominent being

[August 1, 2002 OLC] Memorandum is perhaps the most clearly legally erroneous opinion I have ever heard." Confirmation Hearing on the Nomination of Alberto R. Gonzales to Be Attorney General of the United States: Hearing Before the S. Comm. on the Judiciary, 109th Cong. 158 (2005), available at http://www.access.gpo.gov/congress/senate/pdf/109hrg/99932. pdf.

42 See James Oliphant, Top Cop Must Serve Many Masters: Job Demands Legal, Political, People Skills, Chr. TRIв., Aug. 28, 2007, at 10.

43 See Bazelon et al., supra note 1.

44 Id.

45 See Peter Ackroyd, The Life of Thomas More 313-29, 406 (1998) (discussing how Thomas More's opposition to Henry VIII's creation of the Church of England and his interpretation of heresy laws lead to his execution).

46 See Judiciary Act of 1789, ch. 20, 1 Stat. 73, 92-93 (granting the Attorney General prosecution power); Myers v. United States, 272 U.S. 52, 164 (1926) (holding that the President has the power to appoint and remove executive officers).

47487 U.S. 654 (1988)

48 The initial name of the Act was the Ethics in Government Act. See Pub. L. No. 95521, 92 Stat. 1824 (1978) (codified at 28 U.S.C. \$\$ 591-99) (repealed 1999). For further discussion of the history and content of the Independent Counsel Act, see infra Part IV.B.

49 See Ethics in Government Act $\$ 6$. 
Justice Scalia, who penned the Olson dissent. ${ }^{50}$ Justice Scalia insisted that two checks on Executive Branch powers would inevitably curb any abuses from an Executive who avoids prosecution by her hand-picked Attorney General:

The checks against any branch's abuse of its exclusive powers are twofold: First, retaliation by one of the other branch's use of its exclusive powers: Congress, for example, can impeach the executive who willfully fails to enforce the laws .... Second, and ultimately, there is the political check that the people will replace those in the political branches (the branches more "dangerous to the political rights of the Constitution," Federalist No. 78, p. 465 ) who are guilty of abuse. Political pressures produced special prosecutors-for Teapot Dome and for Watergate, for example $\ldots$. s1

Professor Stephen Carter echoed Justice Scalia's view that there was no need for an independent prosecutor with jurisdiction over Executive Branch officials. ${ }^{52}$ Carter instead places his trust in mass media to cast light on "every ethically questionable molehill" and doubts the extent to which presidents will attempt to control a given prosecutor given the presence of media exposure. ${ }^{53} \mathrm{He}$ also relies on the Legislative Branch to curb Executive misconduct even if criminal charges are never pursued:

So what if the executive branch won't prosecute? The Congress has quite an impressive portfolio of powers of its own, and need not wait for criminal conduct—or rest its judgment on criminal standards-before meting out its own effective means of punishment and control. The Congress, for example, may use committee investigations, backed by subpoena power, to bring to light any malfeasance in the executive branch; it may slash the budget of agencies not doing their jobs; it may decline to confirm presidential nominees for literally hundreds of positions; and, ultimately, it may impeach executive officials and remove them from office. ${ }^{54}$

50 See Morrison, 487 U.S. 697-734 (Scalia, J., dissenting).

51 Id. at 711 (internal citation omitted).

52 See Stephen Carter, Comment, The Independent Counsel Mess, 102 HaRv. L. Rev. 105, 113-15 (1988).

53 See id. at 136.

54 Id. at 136-37 (footnote omitted). 
In the 1990s, one-time supporters of the Independent Counsel Act turned into critics after Kenneth Starr's wide-ranging investigation of President Bill Clinton and argued that the availability of a special counsel who is appointed and controlled by the Attorney General would protect against executive overreach. ${ }^{55}$ Professors Stephen Calabresi and Nicholas Terrell later offered their own vote of confidence for Congress' ability to control executive misconduct via the power of the purse, oversight hearings, and the ability to block confirmations: "The bottom line is that the congressional committees have more sway over the Executive Branch and the bureaucracy than the [p]resident [does]." 56

\section{The Realities of Unchecked Executive Power}

Recent events have not supported this laissez-faire confidence in the existing system of indirect Executive Branch oversight. When the Bush Administration sanctioned torture, Congress did in fact attempt to control Executive Branch malfeasance by the same types of hearings ${ }^{57}$ and media advocacy, ${ }^{58}$ which Carter, Calabresi, and Terrell claimed would be effective. ${ }^{59}$ Led by the public advocacy of Senator John McCain, a sur-

55 See, e.g., James K. Robinson, Luncheon Address, After the Independent Counsel Act: Where Do We Go from Here?, 51 Hastings L.J. 733, 734 (2000). Ironically, Kenneth Starr expressed his own view that the Independent Counsel should be abolished, not because of the problems in his own investigations or the effectiveness of other checks on power, but because the existence of the Independent Counsel Act provided a false sense of security and independent scrutiny. See Future of Independent Counsel Act: Hearing Before the Senate Comm. On Governmental Affairs, 106th Cong. 425 (1999) (Statement of Kenneth Starr, Independent Counsel) ("By its very existence, the Act promises us that corruption in high places will be reliably monitored, investigated, exposed, and prosecuted, through a process fully insulated from political winds. But that is more than the Act delivers, and more than it can deliver under our constitutional system.").

56 Stephen Calabresi \& Nicholas Terrell, The Fatally Flawed Theory of the Unbundled Executive, 93 MinN. L. REv. 1696, 1701 (2009).

57 See, e.g, Department of Justice: Hearing Before the H. Comm. on the Judiciary, 110th Cong. 118-21 (2008) (letter from Rep. Conyers to Michael B. Mukasey, Att'y Gen. of the U.S. (Jan. 31. 2008)) (discussing the issues about which Mukasey would testify, including torture allegations), available at http://judiciary.house.gov/hearings/printers/110th/40741.pdf; Confirmation Hearing on the Nomination of Alberto R. Gonzales to Be Attorney General of the United States: Hearing Before the S. Comm. on the Judiciary, 109th Cong. 14 (2005) (statement of Alberto Gonzales, Att'y Gen. nominee, on torture policies), available at http:// www.access.gpo.gov/congress/senate/pdf/109hrg/99932.pdf [hereinafter Gonzales Senate Confirmation Hearing]; 'DOJ Oversight: Terrorism and Other Topics: Hearing Before the $S$. Comm. on the Judiciary, 108th Cong. 13-16 (2004) (statement of John Ashcroft, Att'y Gen. of the U.S., regarding allegations of torture), available at http://www.access.gpo.gov/congress/ senate/pdf/108hrg/98625.pdf.

58 See, e.g., Press Release, Reps. Jerrod Nadler \& Jane Harman, Nadler, Harman Bills to Restore Habeas Corpus, Ban Torture \& Uphold Geneva Conventions (Mar. 7, 2007), available at http://www.house.gov/list/press/ny08_nadler/HabeasGenevaCorrect030807.html; Press Release, Senator Patrick Leahy, Statement Of Senator Patrick Leahy On The Abuse Of Prisoners in U.S. Military Custody Released to Media (May 4, 2004) (on file with author).

59 See Calabresi \& Terrell, supra note 56, at 1701. 
vivor of torture during his years of captivity during the Vietnam War, Congress enacted the Detainee Treatment Act of $2005,{ }^{60}$ which expressly prohibited cruel, inhuman, or degrading treatment of any person in U.S. custody. ${ }^{61}$ Yet Congress did not appoint a special counsel, and the Executive Branch remained free from accountability for criminal violations of the many pre-existing laws governing prisoner treatment. ${ }^{62}$ Furthermore, the Department of Justice diluted the impact of this new legislation by redefining the Administration's existing torture activities to seemingly conform with the terms of the new law. ${ }^{63}$

The Judicial Branch attempted to intervene in Executive Branch torture practices as well. In the 2006 case of Hamdan v. Rumsfeld ${ }^{64}$ the Supreme Court rejected President Bush's stated detainee policy by holding that the Geneva Conventions' prohibition of mistreatment of war detainees applied to al-Qaeda suspects. ${ }^{65}$ Consistent with existing Court precedent, Hamdan held that intentional infliction of pain for interrogation purposes "shocks the conscience"- the standard that the Senate

60 Pub. L. No. 109-48, 119 Stat. 2739 (2005) (to be codified at 42 U.S.C.).

61 Specifically, the Act provides that "[n]o person in the custody or under the effective control of the Department of Defense or under detention in a Department of Defense facility shall be subject to any treatment or technique of interrogation not authorized by and listed in the United States Army Field Manual on Intelligence Interrogation . . ." Id. \& 1002(a). This prohibition applies regardless where the interrogation is conducted: "No individual in the custody or under the physical control of the United States Government, regardless of nationality or physical location, shall be subject to cruel, inhuman, or degrading treatment or punishment." Id. \$ 1003(a). The Act's definition of "Cruel, Inhuman, or Degrading Punishment or Treatment" contains the same constitutional linkages as did the Senate's Ratification of the International Covenant on Civil and Political Rights, supra note 27; furthermore, the Act took its definition of what constituted cruelty from another set of U.N. understandings: the United States Reservations, Declarations and Understandings to the United Nations Convention Against Torture and Other Forms of Cruel, Inhuman or Degrading Treatment or Punishment done at New York, December 10, 1984. See Detainee Treatment Act § 1003(d); see also U.S. Dep't of Army, Field Manual 2-22.3 (FM 34-52), Human Intelligence Collector OperaTIONs 5-20 (2006), available at http://www.army.mil/institution/armypublicaffairs/pdf/fm2-223.pdf. The Manual sets forth the military's approach to intelligence interrogations and flatly prohibiting the use of force, including all acts of "physical or mental torture or any other form of coercion." Id. Interrogated subjects "may not be threatened, insulted, or exposed to unpleasant or disadvantageous treatment of any kind." Id.

62 Jordan J. Paust, Prosecuting the President and His Entourage, ILSA J. INT'L \& CoMP. L. 539, 546-47 (2008) [hereinafter Paust, Prosecuting the President] (noting that over a fiveyear period "the Bush Administration has furthered a general policy of impunity by refusing to prosecute any person of any nationality under the War Crimes Act or alternative legislation, the torture statute, genocide legislation, and legislation permitting prosecution of certain civilians employed by or accompanying U.S. military forces abroad").

63 See Bradbury Memorandum, in Torture Memos, supra note 18, at 241-74.

64548 U.S. 557 (2006).

65 See id. at 629-30 ("[T]he Government asserts[ ] that Common Article 3 does not apply to Hamdan because the conflict with al Qaeda, being 'international in scope,' does not qualify as a 'conflict not of an international character.' That reasoning is erroneous.") (citation omitted) (additional quotation marks omitted)); Armed Servs., Detainee Treatment, supra note 16 , at xii-xiii. 
adopted when ratifying the Convention Against Torture ${ }^{66}$ - and thus violates the Due Process Clause of the U.S. Constitution. ${ }^{67}$ Again, Department of Justice lawyers responded by simply changing definitions rather than the underlying objectionable activities, as they produced new memoranda that argued that existing CIA activities complied on paper with the judicial rulings. ${ }^{68}$ Perhaps the most notorious example is the August 1, 2002 Memorandum from Jay S. Bybee, Assistant Attorney General to White House Counsel Alberto Gonzales, which claimed that the "severe physical or mental pain or suffering" criminalized under the U.S. statute implementing the Convention Against Torture ${ }^{69}$ must rise to a level associated with "death, organ failure or serious impairment of body functions" in order to constitute torture. ${ }^{70}$ Several years later Harold Hongju Koh, then-Dean of Yale Law School, told Congress that Bybee's opinion was "perhaps the most clearly erroneous legal opinion [he had] ever read."71

The Legislative and Judicial Branches having failed to control Executive Branch torture activities, the only remaining hope was Justice Scalia's "political check" on executive powers. ${ }^{72}$ But if Legislative and Judicial Branch attempts to curb the Executive Branch torture crimes resulted in complete strike-outs, the political check was a sharp line-drive finding its way into the opponent's waiting glove-a more promising prospect that nevertheless resulted in nothing more than the final out.

\section{A New President; Continued Impunity for Torture}

The results of the 2008 presidential election brought hope for a change in torture polices. President-elect Barack Obama was not only from a different political party than his predecessor, but he also expressed sharply critical views of the Bush Administration's activities re-

66 See Convention Against Torture, supra note 26, art. 1.

67 Chavez v. Martinez, 538 U.S. 760, 775 (2003) (opinion of Thomas, J.) (noting that Due Process prohibits conduct that "shocks the conscience"). The justices disagreed about the specific conclusions to be drawn from the facts in the case, but all who addressed the issue of deliberate infliction of pain in order to compel an individual to talk agreed that this practice would shock the conscience and violate the Constitution. See id.

68 See Bradbury Memorandum, in Torture Memos, supra note 18, at 263-72 ("For the reasons stated, we conclude that CIA interrogation techniques, with their careful screening procedures and medical monitoring, do not 'shock the conscience."').

69 Sen. Exec. Rep. 101-30, Resolution of Advice and Consent to Ratification (1990), codified at 18 U.S.C. $\$ 2340$ (2004).

70 See Bybee Memorandum, in Torture Memos, supra note 18, at 43.

71 Gonzales Senate Confirmation Hearing, supra note 57, at 158 (noting that the apparent purpose of the opinion "is to explore how U.S. officials can use tactics tantamount to torture against suspected terrorists, without being held criminally liable . . . Under this absurdly narrow legal definition, many of the heinous acts committed by the Iraqi security services under Saddam Hussein would not be torture").

72 See Morrison v. Olson, 487 U.S. 654, 711 (1988) 
garding torture. ${ }^{73}$ President Obama appointed an Attorney General, Eric Holder, who shared these views, ${ }^{74}$ thereby removing the self-preservation $^{75}$ and conflict-of-interest ${ }^{76}$ barriers that so predictably discouraged the Bush Administration from pursuing torture investigations and prosecutions.

However, since the election, Attorney General Holder's investigative policies have been insufficient, both as a practical matter and under U.S. treaty obligations. In August of 2009, Holder announced that he had asked a federal prosecutor to conduct a preliminary investigation of the CIA's interrogation practices. ${ }^{77}$ But he also pledged that the Department of Justice would not prosecute anyone who "acted in good faith and within the scope of the legal guidance given by the Office of Legal Counsel regarding the interrogation of detainees." 78 Thus, as of late 2010, Holder has pursued neither investigations nor prosecutions of highranking Executive Branch officials from the previous Administration.79 Despite the mandates of the Convention Against Torture, under which the United States explicitly agreed to submit allegations of torture to authorities for criminal prosecution, ${ }^{80}$ it appears that none of the Executive

73 See, e.g., Josh Rovenger, Analysis: Obama vs. McCain on Torture, Chrizens for Global Change, May 28, 2008, http://www.globalsolutions.org/in_the_news/analysis_obama_vs_mccain_torture (quoting President Obama as saying, "What we cannot do is have the President of the United States state, as a matter of policy, that there is a loophole or an exception where we would sanction torture"); Transcript: President Obama's 100th-Day Press Briefing, N.Y. Times, Apr. 29, 2009, http://www.nytimes.com/2009/04/29/us/politics/ 29text-obama.html?pagewanted=4 (quoting President Obama as saying, "I believe that waterboarding was torture. And I think that ... whatever legal rationales were used, it was a mistake").

74 See Scott Shane, Remarks on Torture May Force New Administration's Hand, N.Y. Times, Jan. 16, 2009, at A12 (quoting Attorney General Holder at his congressional confirmation hearing as saying, "We prosecuted our own soldiers for using it in Vietnam . . . . Waterboarding is torture.").

75 See supra notes 31-36 and accompanying text.

76 See supra notes 37-46 and accompanying text.

77 See Carrie Johnson, Prosecutor to Probe CIA Investigations, Wash. Post, Aug. 25, 2009, http://www.washingtonpost.com/wp-dyn/content/article/2009/08/24/AR20090824017 43.html.

78 See Press Release, U.S. Dep't of Justice, Attorney General Eric Holder Regarding a Preliminary Review into the Interrogation of Certain Detainees (Aug. 24, 2009) [hereinafter Holder Press Release], available at http://www.justice.gov/ag/speeches/2009/ag-speech0908241.html ("[T] he Department of Justice will not prosecute anyone who acted in good faith and within the scope of the legal guidance given by the Office of Legal Counsel regarding the interrogation of detainees. I want to reiterate that point today, and to underscore the fact that this preliminary review will not focus on those individuals. I share the President's conviction that as a nation, we must, to the extent possible, look forward and not backward when it comes to issues such as these.").

79 See Jonathan Turley, Op-Ed., Appoint a Prosecutor for War Crimes, L.A. TIMEs, Oct. 18,2009 , at A31.

80 See Convention Against Torture, supra note 26, at art. VII. 
Branch officials who sanctioned torture will be subject to criminal prosecution in the United States. ${ }^{81}$

Why have President Obama and his Attorney General not pursued criminal prosecution of these Executive Branch torture crimes? When asked about conducting investigations and filing indictments, the President did not dismiss the possibility outright, but said, "Generally speaking, I'm more interested in looking forward than looking backwards." There is a clear political element to this desire to "move on," which the President himself articulated when campaigning for election: "I would not want my first term consumed by what was perceived on the part of the Republicans as a partisan witch hunt, because I think we've got too many problems to solve." 83 The fear of political distraction caused by torture prosecutions may indeed be valid, and the President's wide array of responsibilities suggests that the electorate is less likely to punish him for dereliction of a particular law enforcement duty. ${ }^{84}$

Although Obama's statements unsurprisingly appear to echo in Attorney General Holder's subsequent prosecutorial decisions, ${ }^{85}$ it is also important to note that U.S. prosecutions of Executive Branch officials for sanctioning torture would not be easy. In general, it is notoriousiy difficult to convict "law enforcement" defendants of criminal charges, not to mention high-profile leaders of the nation's government. ${ }^{86}$ Specifically, officials facing torture charges can use the U.S. criminal law defense of "reasonable reliance" by showing that government officials advised them that their conduct was lawful. ${ }^{87}$ Congress added another prosecutorial barrier when it enacted the Military Commissions Act of 2006 and pledged immunity to post-9/11 interrogators. ${ }^{88}$ Further, the Department of Justice Office of Legal Counsel memoranda were clearly requested and designed to provide legal cover to U.S. officials who approved and

81 See discussion infra Part IV.C.4. (prosecutions of high-ranking executive branch officials are being contemplated in other jurisdictions outside the United States).

82 Leahy Calls for "Truth Commission" on Torture, CNN.com, Mar. 4, 2009, http:// www.cnn.com/2009/POLITICS/03/04/leahy.commission/index.html.

83 Mark Benjamin, Would Obama Prosecute the Bush Administration for Torture?, $\mathrm{S}_{\mathrm{A}}$ LON (Aug. 4, 2008, 08:00 AM), http://www.salon.com/news/feature/2008/08/04/obama/.

84 See infra notes 144-46 (noting that President Bush won re-election in 2004 despite the public's belief that the United States was engaging in illegal torture and its opposition to the practice).

85 See Holder Press Release, supra note 78.

86 See Steven Puro, Federal Responsibility for Police Accountability Through Criminal Prosecution, 22 St. Louis U. Pub. L. Rev. 95, 103-04 (2003) (noting that between 1984 and 1995, the Criminal Section of the U.S. Department of Justice had a seventy one percent success rate in prosecuting law enforcement officers charged with civil rights violations, in contrast to its ninety five percent success rate for prosecuting non-law enforcement individuals).

87 See Raley v. Ohio, 360 U.S. 423, 438-39 (1959).

88 See Military Commissions Act of 2006, Pub. L. No. 109-366, § 8(b)(1)-(3), 120 Stat. 2600,2636 (to be codified at 18 U.S.C.). 
participated in torture. ${ }^{89}$ As former Office of Legal Counsel attorney Jack Goldsmith notes, the Justice Department considered OLC opinions as "advance pardons" or "get-out-of-jail-free" cards dispensed to government officials who relied on the opinions. ${ }^{90}$

However, the immunity-conferring power of an Office of Legal Counsel opinion has recently been called into serious question from a legal standpoint. ${ }^{91}$ In fact, if charges are filed against Bush Administration officials, the circumstances surrounding the composition of the torture memoranda will surely limit their prophylactic effect: through them, the Office of Legal Counsel attempted to redefine torture in the face of settled law ${ }^{92}$ and only made this attempt after oral discussions with Bush Administration regarding the types of techniques the Administration wished to employ on detainees. ${ }^{93}$ As the Nuremberg Military Tribunals show, the defense of reliance on internal directives attempt to pain controversial activities as legal can be rejected. ${ }^{94}$ The efficacy of the congressionally-promised immunity from the Military Commissions Act is similarly dubious. ${ }^{95}$

Potential criminal prosecution could be based on several grounds brought independently or jointly: direct violation of the Convention Against Torture (described above), aiding and abetting of an international crime, participation in a joint criminal enterprise, or dereliction of duty by civilian and military leaders. ${ }^{96}$ Federal prosecution could proceed pursuant to the War Crimes Act $^{97}$ or the federal torture statute ${ }^{98}$ or

89 See Torture Memos, supra note 18 , at 14.

90 Jack Goldsmith, The Terror Presidency: Law and Judgment Inside the Bush AdMINISTRATION 96-97 (2007).

91 See Note, The Immunity-Conferring Power of the Office of Legal Counsel, 121 HARv. L. REv. 2086, 2091-92 (2008).

92 See supra notes 23-30 and accompanying text.

93 See Mark Mazzetti, Bush Aides Tied to Talks on CIA Interrogations, N.Y. TIMEs, Sept. 25, 2008, at A14, available at http://www.iht.com/articles/2008/09/25/america/cia.php (stating that Office of Legal Counsel attorney and torture memo author, John Yoo, gave oral advice regarding interrogation methods before formal memoranda were produced).

94 See In re Von Leeb (German High Command Trial), 15 INT'L L. REPS. 376, 395-96 (1948) ("A directive to violate International Criminal Common Law is . . void and can afford no protection to one who violates such law in reliance on such a directive."); see also Michael P. Scharf, Seizing the "Grotian Moment": Accelerated Formation of Customary International Law in Times of Fundamental Change, 43 CORNELL INT'L L.J. 439, 465-67 (2010) (noting that although the International Law Commission originally distinguished between offenses made pursuant to superior orders, it eventually abandoned that distinction).

95 See Paust, Absolute Prohibition, supra note 30 , at 1548 \& n.58 ("Congress has no power to violate the separation of powers by such a blatant denial of a constitutionally mandated, traditional, and essential judicial power to implement treaty law of the United States that, as the Constitution expressly requires, "shall extend to all cases . . . arising under . . . treaties.[']") (citation omitted).

96 See Paust, Prosecuting the President, supra note 62, at 542-43.

97 See 18 U.S.C. $\S 2441$ (2003).

98 See 18 U.S.C. $\$ \S 2340-2340$ A (2000). 
both. Indeed, potential legal barriers have not prevented the Obama Administration from reviewing possible criminal prosecution against lowlevel torture actors. ${ }^{99}$ That Attorney General Holder has not instigated similar inquiries into the roles of high-level Executive Branch officials seemingly has more to do with President Obama's acknowledged political calculus than the actual challenges of criminal law.

Ultimately, the critical question is not whether torture prosecutions would be successful or even politically damaging but, rather, whether the United States will live up to its obligations to pursue such crimes as those obligations are set out under international agreements and the rule of law handed down over generations of American jurisprudence. It seems clear that the Obama-appointed Attorney General has no more intention to fulfill these obligations than the Bush-appointed Attorneys General did. Thus, when confronted with multiple and egregious violations of the laws against torture, the "political check" on Executive Branch misconduct has been no more effective than the Legislative and Judicial attempts to sanction torture. Sadly, while Bush Administration attorneys may have misstated the law on torture, they correctly assessed the minimal risk of judicial review of Executive Branch actions. In one memorandum, Department of Justice attorneys admitted that their permissive interpretation of the law on torture might not be upheld by a reviewing court, but they gave our country's leaders the chillingly accurate assurance that there was little to worry about since "the courts have nothing to do and can give no redress." 100 The memorandum concluded that although "we cannot predict with confidence whether a court would agree with [our] conclusion [that enhanced interrogation techniques are legal], . . . the question is unlikely to be subject to judicial inquiry."101

When a new President takes office, the fox may no longer be guarding the henhouse, but as the torture memo fiasco shows, he can still slink away in impunity with feathers and chicken bones trailing in his wake. The country's founders who were dedicated to curbing unchecked powers certainly would not approve of this state of affairs. As it turns out, the history of the creation of the office of Attorney General, and the establishment of our system of federal prosecution, shows that the foun-

99 See Holder Press Release, supra note 78.

100 Bradbury Memorandum, in Torture Memos, supra note 18, at 272 (citation omitted). In his analysis of these concluding remarks in the memorandum, David Cole writes:

In other words, when it comes to the ban on cruel, inhuman or degrading treatment, the CIA operates for all practical purposes in a "law-free zone," or at least in a zone where the law is what the executive says it is-in secret-and no court will ever have the opportunity to disagree.

Id. at 34 .

101 Id. at 274. This final memo of May 2005, was the bookend to the first memo of August 2002, which argued that neither the Legislative or Judicial Branch have any authority to question the President's actions with regard to detainees. See id. at 85-90. 
ders never intended for the President to exercise the exclusive control over federal criminal prosecution that has led our current state of Executive impunity.

\section{The Missing Legal and Historical Foundations for President-Controlled Federal Prosecutions}

\section{A. The English and Colonial Traditions}

English tradition informed the founders in many aspects of government design including the creation of a chief legal officer. Beginning in the Middle Ages, the Attorney General in England was at once the chief legal advisor to the Crown, a consultant to both houses of Parliament, and the chief administrator of the attorneys who acted on his behalf in representing government agencies in court. ${ }^{102}$ Although individuals could bring criminal charges, the Attorney General retained the ability to defeat a prosecution by filing a writ of nolle prosequi. ${ }^{103}$ Under the reign of Henry VIII, the Attorney General began serving at the pleasure of the crown, rather than under life tenure. ${ }^{104}$ At the time of the United States' founding, all thirteen colonies followed this model, with some variations: Rhode Island popularly elected its attorney general, North Carolina legislatively granted lifetime appointments, and New York and Delaware the governors appointed their attorneys general. ${ }^{105}$ The individual colonies and new states imported English common law and, with it, the dual nature of the office of attorney general as the chief legal officer for both the citizens and the executive. ${ }^{106}$

\section{B. The Constitutional Convention and the First Congress}

The constitutional framers' creation of a unitary executive was a deliberate and bold act.107 The executive councils of government under the Articles of Confederation had been remarkably diffuse and just as

102 See William P. Marshall, Break Up the Presidency? Governors, State Attorneys General, and Lessons from the Divided Executive, 115 YALE L.J. 2446, 2449 (2006).

103 See S.F. Milsom, Historical Foundations of the Common Law 404-05 (2d ed. 1981) (providing historical background regarding prosecutorial intervention); Rebecca Krauss, The Theory of Prosecutorial Discretion in Federal Law: Origins and Development, 6 SETON Hall Circuit Rev. 1, 16 (2009) (describing the concept of nolle prosequi).

104 See Marshall, supra note 102, at 2449.

105 See id. at 2450-51.

106 See Jay L. Himes, STate Parens Patriae Authority: The Evolution of the State Attorney General's Authority 21 (2004), available at http://www.abanet.org/antitrust/at-committees/at-state/pdf/publications/other-pubs/parens.pdf.

107 See U.S. Const. art. II, $\S 1$, cl. 1; see also Catherine Drinker Bowen, Miracle at PhIladelphia 55 (1966) (describing a hush falling over the convention when a single executive was first proposed). The term "unitary executive" here refers to a structure with a single executive officer, not to be confused with the argument for a presidential prerogative to act contrary to legislation. See infra note 137. 
remarkably ineffective, ${ }^{108}$ which inspired James Madison to argue in Federalist No. 51 that a divided executive would be too weak to compete effectively with the Legislative and Judicial Branches and not jeopardize the necessary checks and balances. ${ }^{109}$ Alexander Hamilton, in Federalist No. 70, insisted that a unitary executive fosters energy and efficiency, and criticized a plural executive as "tend[ing] to conceal faults, and destroy responsibility." 110

This pre-convention lobbying, and the clear (if sparse) language of Article II, Section 1 ("The executive power shall be vested in a President of the United States of America.") ${ }^{111}$ notwithstanding, the framers would not have opposed a system of federal criminal prosecution independent of the executive. They were well aware of the independent prosecution model used by England and several of the original states. ${ }^{112}$ However, they neither took action to define the office of Attorney General in the text of the Constitution nor appear to have conducted any debate on the appointment, removal, or duties of the country's chief legal officer. ${ }^{113}$ Instead, it was left to the First Congress to establish the office. ${ }^{114}$

Congress, too, did not seem to feel strongly about the need for a dependent relationship between the Attorney General and the President, ${ }^{115}$ and, likely, did not even consider the general issue of presidential control over federal prosecutions. In initial drafts of the Judiciary Act of 1789, the Supreme Court appointed the Attorney General. ${ }^{116}$ The limited records available suggest that it was only conflict-of-interest concerns raised by the Judiciary, not a desire for presidential control, that led to Congress creating the Attorney General's office with a presidential relationship in the final sentences of the Judiciary Act:

108 See Letter from James Madison to Edmund Pendleton (Feb. 24, 1787), in 9 THE PAPERS OF JAMES MADISON 294-95 (Robert A. Rutland \& William M.E. Rachal eds., 1975) ("Indeed the present System neither has nor deserves advocates; and if some very strong props are not applied will quickly tumble to the ground.").

109 The Federalist No. 51, at 321-22 (James Madison) (Clinton Rossiter ed., 1961) ("[T] he great security against a gradual concentration of the several powers in the same department, consists in giving to those who administer each department the necessary constitutional means and personal motives to resist encroachments of the others. The provision for defense must in this, as in all other cases, be made commensurate to the danger of attack. Ambition must be made to counteract ambition.").

110 ld. at No. 70, at 427 (Alexander Hamilton) ("But one of the weightiest objections to a plurality in the Executive, and which lies as much against the last as the first plan, is, that it tends to conceal faults and destroy responsibility.").

111 U.S. Const. ant II, \& 1, c1. 1.

112 See Susan Low Bloch, The Early Role of the Attorney General in Our Constitutional Scheme: In the Beginning There Was Pragmatism, 1989 DuKE L.J. 561, 564 n.11, 603-04 (1989).

113 See id. at 570.

114 See id. at 570-71.

115 See id. at 571.

116 See id. at 589. 
And there shall ... be appointed a meet person, learned in the law, to act as attorney-general for the United States, who shall be sworn or affirmed to a faithful execution of his office; whose duty it shall be to prosecute and conduct all suits in the Supreme Court in which the United States shall be concerned, and to give his advice and opinion upon questions of law when required by the President of the United States, or when requested by the heads of any departments, touching any matters that may concern their departments, and shall receive such compensation for his services as shall by law be provided. ${ }^{117}$

Congress was silent on the question of to whom the Attorney General should report within the new government. As Susan Low Bloch has pointed out, this lack of specificity was in marked contrast to the Constitution's and Congress' very explicit efforts to invest significant presidential authority over other government officials:

Although the framers decided that the Constitution should vest the executive power in a single Presidentnot a "plural executive"-none of the early interpreters seemed to believe that that constitutional decision dictated that the President have the same degree of control over all executive officers. To be an effective head of state, the President needed maximum control over the Secretaries of War and Foreign Affairs and, accordingly, was given the power to appoint and remove these officers and to direct their activities. However, with the Attorney General, where centralized control was apparently not deemed essential, the President was explicitly given only the power to appoint; the power to remove and to direct were left unspecified. ${ }^{118}$

Other historians have reviewed this same record and concluded that exclusive Executive Branch control over law enforcement has neither constitutional nor historical foundation. ${ }^{119}$

117 Judiciary Act of 1789 , ch. 20,1 Stat. 73,93 . Bloch also notes the absence of a significant record of why the final version of the Act departed from judicial appointment of the Attorney General but suggests it may have been inspired by judges' suggestions to members of Congress. See Bloch, supra note 112, at 571 n.32.

118 Bloch, supra note 112 , at 636-37.

119 See, e.g., Harold J. Krent, Executive Control over Criminal Law Enforcement: Some Lessons from History, 38 AM. U. L. REv. 275, 281-310 (1989); Lawrence Lessig \& Cass R. Sunstein, The President and the Administration, 94 ColuM. L. REv, 1, 15-22 (1994). 


\section{Post-Founding Evolution of the U.S. Attorney General}

In 1792, one Supreme Court justice insisted that the Attorney General was empowered to respond to the interests of the government regardless of explicit presidential approval, remarking: " $[\mathrm{H}] \mathrm{e}$ is not called the Attorney General of the President, but Attorney General of the United States." 120 Consequently, for many decades after its creation, the U.S. Attorney General did not hold a particularly important or powerful position, and the office did not appear exclusively attached to the President. ${ }^{121}$ Instead, the Attorney General performed a part-time job with neither staff nor office space and appeared to report to, and serve, Congress as much as the President. ${ }^{122}$ He had no supervisory authority over district attorneys who operated as semi-autonomous assistants to judges and grand juries. ${ }^{123}$

In the mid-nineteenth century, however, the power of both the Attorney General and the entire Executive Branch began to grow, and this would impact how the two interacted with each other. The Attorney General started receiving a salary on par with other cabinet officials, then gained control over district attorneys and marshals, and eventually oversaw a fully staffed Department of Justice. ${ }^{124}$ As the Office of the Attorney General expanded its reach, so did the broader Executive Branch in relation to the Judicial and Legislative Branches. ${ }^{125}$ The dramatic impact of these changes have led some to conclude that both the Attorney General and the President he serves have become more similar to the Henry VIII-Thomas More model than the framers would ever have imagined possible. ${ }^{126}$

120 Bloch, supra note 112, at 606 (citing Notes and Memoranda from James Iredell, Justice, U.S. Supreme Court (1792) (on file with the North Carolina State Department of Archives, Charles E. Johnson Collection)).

121 Krent, supra note 119 , at 286-89.

122 Bloch, supra note 112 , at 581-82.

123 Homer Cummings \& Carl McFarland, Federal Justice 17, $142-43$ (1937).

124 Act of June 22, 1870, ch. 150, $\S 1,16$ Stat. 162 ("There shall be, and is hereby, established an executive department of the government of the United States, to be called the Department of Justice, of which the Attorney General shall be the head. His duties, salary, and tenure of office shall remain as now fixed by law, except so far as they may be modified by this act.").

125 See, e.g., Steven G. Calabresi \& Christopher S. Yoo, The Unitary Executive During the First Half-Century, 47 CASE W. REs. L. Rev. 1451 (1997); Steven G. Calabresi \& Christopher S. Yoo, The Unitary Executive During the Second Half-Century, 26 HARv. J.L. \& PuB. PoL'y 667 (2003); Christopher S. Yoo et al., The Unitary Executive During the Third HalfCentury, 1889-1945, 80 Notre Dame L. Rev. 1 (2004); Christopher S. Yoo et al., The Unitary Executive In The Modern Era, 1945-2004, 90 Iowa L. Rev. 601 (2004).

126 See, e.g., Martin S. Flaherty, The Most Dangerous Branch, 105 YALE L.J. 1725, 1727 (1996) ("The dominance of executive power ought by now, to lift a phrase from Charles Black, to be a matter of common notoriety not so much for judicial notice as for background knowledge of educated people who live in this republic."). William Marshall points out that 


\section{More Prosecutorial Independence Would Lead to BETTER GOVERNANCE}

Several commentators have argued that the establishment of a prosecutor who operates independently of the Executive Branch would not only avoid the aforementioned conflicts of interest but also lead to greater transparency in decision-making ${ }^{127}$ and accountability to voters. ${ }^{128}$ An independent prosecutor would allow the electorate to have a more direct impact on policy because prosecutorial decision-making would not be wedded to the plethora of issues in the presidential election that would otherwise cloud such thinking. ${ }^{129}$ These observations are more than just theory; recent evidence supports the proposition that prosecutorial independence from executive control will lead to both more electorate confidence and better governance overall. ${ }^{130}$

\section{A. Empirical Evidence That Executive Control over Prosecution Increases Chances of Corruption}

In 2008, Anne van Aaken, Lars Feld, and Stefan Voigt tested the hypothesis that prosecution agencies that depend on the Executive have less incentive to prosecute government actors, thus reducing these actors'

the unitary executive framework commands this result notwithstanding any pre-established checks:

On paper at least, there is a watchdog guarding against executive branch excess ... . But under the unitary executive framework, it is the President's, and not the Attorney General's, position on the duties and obligations of the Office that controls. And by his power of appointment or otherwise, the President can assure that the Attorney General's and Department of Justice's primary fealty is to his Administration and not to some abstract view of the law. Without any structural assurance of independence, in short, the Office of the Attorney General is only as independent as the President wants it to be.

Marshall, supra note 102, at 2470-71.

127 See Marshall, supra note 102, at 2475.

128 See Peter M. Shane, Political Accountability in a System of Checks and Balances: The Case of Presidential Review of Rulemaking, 48 ARK. L. REv. 161, 196-99 (1994) [hereinafter Shane, Political Accountability].

129 See Viggiano, supra note 38, at 1208 ("It is also unlikely that displeasure with the actions taken by the Attorney General would be the issue foremost in the mind of a voter on Election Day when he or she must also be considering the nation's foreign policy, economy, and overall domestic agenda. Impeachment is an equally unattractive alternative remedy, since displeasure with one cabinet member's behavior does not seem to be a reasonable basis upon which to impeach the President.").

130 It is worth noting that new democracies in Eastern Europe have been characterized by their separation of the chief prosecutor from executive control. See Darina Šábyová, Role and Status of the Public Prosecution Service, in What Public Prosecution IN Europe IN The 21st Century: Proceedings of the Pan-European Conference 79 (2000); Alenka Šelih, The Prosecution Process and the (Changing) Role of the Prosecutor, in CRIME AND CRIMINAL JUSTICE IN EUROPE 93, 96-97 (2000) (advocating for appointments of a fixed period of time in order to avoid prosecutors being dependent on other government officials, and noting that new Eastern European governments are likely to have their chief prosecutors chosen by parliament to avoid dominance of the position by the chief executive). 
risk of sanction for misconduct. ${ }^{131}$ In so doing, they evaluated whether an independent prosecutorial agency reduced the likelihood of government officials committing crimes. ${ }^{132}$ To test their hypothesis, they constructed two cross-national indicators of prosecutorial independence. ${ }^{133}$ The first indicator measured seven variables of de facto prosecutorial independence including executive power to remove prosecutors, budget and salary adequacy and independence, and fluctuations in the legal foundation for prosecuting official misconduct. ${ }^{134}$ Collecting data from seventy-eight countries and comparing the results to local perception of corruption, they concluded that de facto prosecutorial independence was highly and robustly significant in explaining variation in measures of perceived corruption. ${ }^{135}$ These results support the intuitive assumption that independent prosecutorial oversight decreases the occurrence of official misconduct. ${ }^{136}$

\section{B. Empirical Evidence That an Unbundled Executive Provides More Effective Governance}

As discussed in subpart B of Part II, the U.S. federal system features a unitary executive with a wide and seemingly broadening array of powers vested in the President alone. Christopher Berry and Jacob Gersen argue that public preferences would be better served by "unbundling" the federal Executive, i.e., directly electing one or more federal officials such

131 See Anne van Aaken et al., Power over Prosecutors Corrupts Politicians: Cross Country Evidence Using a New Indicator 1 (MAGKS Joint Discussion Series on Economics No. 01-2008), available at http://www.uni-marburg.de/fb02/makro/forschung/magkspapers/ 01-2008_voigt.pdf.

132 See id. at 15 (noting that de facto independence reduces crimes, while de jure independence does not).

133 See id. at 2.

134 See id. at 10-12.

135 See id.

136 Van Aaken et al. also conducted analyses of de jure prosecutorial independence showing a negative relationship to de facto prosecutorial independence and a positive relationship to perceived corruption, which they suggest reflects the pressure exerted on governments by international development agencies to adopt anti-corruption measures. Id. at 16 . Their analysis showed that the de jure measure was significantly impacted by recently-passed legislation promising procedural improvements that did not yet show up as having a de facto impact. For example, Aaken et al.'s measures showed that the presence of an anti-corruption agency, presumably created in response to incidents of official misconduct, had an overall positive relationship to corruption measures. Id. at 18 . Findings indicating that promises do not equal performance are consistent with Oona Hathaway's quantitative analysis of countries' failures to live up to their human rights treaties. See Oona A. Hathaway, Do Human Rights Treaties Make a Difference?, 111 Y ALE L.J. 1935, 1976-2000 (2002) (finding, in some cases, that ratification of such treaties was associated with worse practices); see also Fran Quigley, Growing Political Will from the Grassroots: How Social Movement Principles Can Reverse the Dismal Legacy of Rule of Law Interventions, 41.1 Colum. Hum. RTs. L. Rev. 13 (2009) (discussing the disparity between Kenya's formal human rights pledges and its administration of justice). 
as the Attorney General. ${ }^{137}$ Peter Shane agrees and lays out the problem of an electorate choosing a President who is invested with the responsibility for an overstuffed portfolio of issues:

There is no evidence that the President, at any given moment, embodies that set of policy predilections across a wide set of issues that is held by a contemporaneous majority-or, more accurately, by contemporaneous majorities of Americans . . . . There is one most obvious reason why the President would mirror public opinion polls quite imperfectly-the President is a single person. Assuming it is even possible to identify, at a given moment, the full array of value judgments that various majorities of Americans hold across a comprehensive range of important public policy issues, it is doubtful that the resulting attitudinal profile would be sufficiently coherent to impute it to any single personality. ${ }^{138}$

In contrast to van Aaken, Feld, and Voigt's cross-national evaluation of political systems, Berry and Gersen focus on U.S. state and local governments where the dominant model is an unbundled Executive. ${ }^{139}$ Analyzing these government models, Berry and Gersen show that adding executive-level officials produces greater clarity in voter control over policy issues and shifts policy outcomes toward voter preferences. ${ }^{140}$ Timothy Besley and Stephen Coate produced similar results in the context of state utility regulators in the United States: those regulators who adopted more consumer-friendly policies were elected, rather than appointed, to their positions. ${ }^{141}$

Increasing the number of elected executive officeholders, according to Berry and Gersen, will ensure that government policy is more line with citizen preferences-at least while the number of officeholders remains small enough for the public to effectively monitor. ${ }^{142}$ Applying the relevant data, the authors wrote:

137 Christopher R. Berry \& Jacob E. Gersen, The Unbundled Executive, 75 U. CHI. L. REv. 1385, 1387 (2008) (hereinafter Berry \& Gersen I).

138 Shane, Political Accountability, supra note 128, at 197-98.

139 See Berry \& Gersen I, supra note 137, at 1386 (citing data that forty two states elect their attorneys general).

140 See Christopher R. Berry and Jacob E. Gersen, Fiscal Consequences of Electoral Institutions, 52 J.L. \& ECON, 469, 491 [hereinafter Berry \& Gersen II].

141 See Timothy Besley \& Stephen Coate, Elected Versus Appointed Regulators: Theory and Evidence, 1 J. Eur. ECON. Ass'N 1176, 1200-01 (2003).

142 See Berry \& Gersen II, supra note 140, at 470 . Berry and Gersen's evaluations show a U-shaped relationship between the number of elected officials in local government and patterns of government taxing and spending. See id. This supports the theory that increasing the number of elected officials increases accountability, providing a net positive effect until the costs of monitoring the increasing number of officials outweighs that benefit. See id. 
An unbundled executive systematically reduces agency problems in representative government by enhancing accountability to natural citizen constituencies .... [A] vote for or against a presidential candidate is remarkably crude; it is a weighted average of voter approval of dozens if not hundreds of policy dimensions. A vote for or against an elected secretary of education is less so. ${ }^{143}$

The electorate's difficulty in fully expressing its policy preferences through a single presidential vote gained further credence during the 2004 presidential election. At the start of his second term, President Bush claimed the 2004 election and its results were his "accountability moment." 144 Yet, poll numbers indicate that his re-election was not a statement of widespread approval for all of his Administration's actions. Public opinion data in the summer of 2004 showed that Americans disapproved of torture by a 2-1 margin and that most Americans believed that the Bush Administration was in fact conducting such torture. ${ }^{145}$ Yet Bush was re-elected to office that same November by voters who cited other priorities such as the war in Iraq, the economy, and health care. ${ }^{146}$

It seems clear that Bush's re-election was not a statement of widespread approval for his Administration's torture actions. By extension, it is quite possible that an independent Attorney General candidate who pledged to vigorously investigate and prosecute torturers and their enablers would have won election in the same contest. Such an outcome would have reduced the slack between voter preferences and executive action that Berry and Gersen identify ${ }^{147}$ and better preserved the defense of the rule of law.

\section{Options for Independent Prosecutorial Oversight of the EXECUTIVE BRANCH}

\section{A. Direct Election of a Federal Attorney General}

The obvious fox-guarding-the-henhouse flaw of placing prosecutorial authority in the hands of the President of the United States-who could also be the target of such prosecution-suggests an

\footnotetext{
143 Berry \& Gersen I, supra note 137, at 1387, 1405 .

144 Interview by Michael A. Fletcher \& Jim VandeHei with George W. Bush, President, United States of Am., aboard Air Force One (Jan. 14, 2005), reprinted as Transcript of Bush Interview, WASH. PosT, Jan. 16, 2005, http://www.washingtonpost.com/ac2/wp-dyn/A12570$2005 \operatorname{Jan} 15$.

145 David Morris \& Gary Langer, Most Americans Oppose Torture Techniques, ABCNews.сом, May 27, 2004, http://abcnews.go.com/sections/us/Polls/torture_poll_040527. html.

146 Poll: Voters Relieved by Decisive Election, USA TODAY.COM, Nov. 8, 2004, http:// www.usatoday.com/news/politicselections/2004-11-08-voters-relieved_x.htm.

147 See Berry \& Gersen II, supra note 140, at 471.
} 
equally obvious solution: the direct election of a federal Attorney General. In his provocatively titled essay, Break Up the Presidency, Professor William Marshall argues that an elected Attorney General would be clearly independent of the President and directly accountable to the electorate. ${ }^{148}$ The office would then mirror the dominant model for the selection of state attorneys general and local-level prosecutors. ${ }^{149}$ Although removing the Attorney General from the purview of the President would arguably require a constitutional amendment to Article II, 150 preserving the integrity of a government in which no officeholder is above the law justifies such an extraordinary measure. ${ }^{151}$

Defenders of the "unitary executive" status quo-who should not be confused with those who support a similarly-labeled theory of presidential prerogative to act contrary to legislation ${ }^{152}$-argue that a shift towards electing more federal officials would tax the attention span of voters, weaken the Executive Branch in relation to the Legislative, and blur the boundaries of executive power in times of national crisis. ${ }^{153}$

148 See Marshall, supra note 102, at 2476.

149 See Eric Rasmusen et al., Convictions Versus Conviction Rates: The Prosecutor's Choice, 11 AM. L. \& ECON. REv. 47, 67-68 (2009) (citing the fact that chief prosecutors are elected everywhere except for Alaska, Connecticut, the District of Columbia, and New Jersey). The article notes that "[i]n Alaska, Delaware and Rhode Island, criminal prosecution is the primary responsibility of the Attorney General (appointed in Alaska and elected in Delaware and Rhode Island) and in the District of Columbia the U.S. Attorney has jurisdiction over felonies and misdemeanors." $I d$.

150 See Reno v. Am.-Arab Anti-Discrimination Comm., 525 U.S. 471, 489-90 (1999) (citing United States v. Armstrong, 517 U.S. 456, 463-65 (1996) (noting that prosecutorial discretion is "special providence" of the Executive Branch)); Proposals Regarding an Independent Attorney General, 1 U.S. Op. Off. Legal Counsel 75, 77-78 (1977) (concluding that proposals to make the Attomey General independent would be a violation of the constitutional charge that the President "shall take Care that the Laws be faithfully executed") (quoting U.S. Const. art. II, § 3)). But see supra notes 113-18 for a discussion of evidence suggesting that the framers did not specifically address the question of whether the Attorney General would be appointed by the President and that the first Congress did not see presidential control of federal prosecutions as a constitutional mandate.

151 See, e.g., Marbury v. Madison, 5 U.S. (1 Cranch) 137, 163 (1803). Berry and Gersen acknowledge the difficulty of enacting constitutional changes but also note the trend towards directly-elected executive offices at state and local levels and argue that there is ample reason to be open to such a change at the federal level. See Berry \& Gersen I, supra note 137, at 1428-29 "The structure of the executive branch has changed enormously since the founding .... As society changes, political institutions do as well. If old unbundled executives should be eliminated and new unbundled executives create, so be it.").

152 Calabresi \& Terrell, supra note 56, at 1697.

153 See id. at 1705, 1712, 1739. Berry and Gersen are the main foils for the Calabresi and Terrell argument, but they return the favor with a humorous but pointed refutation of any suggestion that an unbundled executive would lead to lesser candidates for the presidency:

The candidates most likely to run for president in the current regime who would not do so in the unbundled regime are likely to be candidates for whom aggregate power is the most important concern. These candidates prize being the person in control of everything. Perhaps this group of candidates makes for especially good presidents, but they seem to have most in common with megalomaniacs. In other countries, this 
However, these arguments are refuted by the empirical evidence of increased public confidence in "divided" executives cited in Part III. Further, an independent attorney general arrangement is the predominant method at the state level ${ }^{154}$ and has never been reversed by a state that adopted it. ${ }^{155}$ These facts not only support one explicitly identifiable reason for keeping the state attorneys general independent of the Governor-to check the power of the states' chief executives ${ }^{156}$-but also serve as a harbinger of the state-level trend toward increasing the number of directly elected executive officers. ${ }^{157}$ States most often invest prosecutorial powers in local prosecuting attorneys, ${ }^{158}$ and almost all local jurisdictions elect their local chief prosecutors. ${ }^{159}$ Since state and local prosecutors handle a much heavier caseload than their federal counterparts, ninety-five percent of felony criminal cases in the United States are investigated, filed, and pursued by prosecutors accountable to direct election. ${ }^{160}$ Thus, independent election of a chief legal officer is not an unproven model, or even an imported one. Rather, it is the dominant model of prosecution in the United States.

Aligning the federal Executive elections process with established state procedures also resolves the inherent conflicts of interest arising from presidential control over a would-be prosecutor. ${ }^{161}$ An elected prosecutor who chose to ignore her local executive branch's transgres-

would be a group of likely dictators, not responsive and responsible officials. Making the election of megalomaniacs or aspiring dictators less likely hardly seems a mark of shame for any executive regime.

Berry \& Gersen I, supra note 137 , at 1420.

154 See 40 Council of State Gov'ts, The Book of the States 232 tbl.4.19 (2008 ed.) (identifying forty-five states in which the Attorney General is independent of the governor).

155 See Marshall, supra note 102, at 2452.

156 See id. at 2451-52 (quoting State ex rel. Mattson v. Kiedrowski, 391 N.W.2d 777, 782 (Minn. 1986)). In Mattson, the Minnesota Supreme Court outlined the state's rationale for independent executive officers:

Rather than conferring all executive authority upon a governor, the drafters of our constitution divided the executive powers of state government among six elected officers. This was a conscious effort on the part of the drafters, who were well aware of the colonial aversion to royal governors who possessed unified executive powers.

Mattson, 391 N.W.2d at 782.

157 Berry \& Gersen I, supra note 137 , at 1400.

158 See Robert Misner, Recasting Prosecutorial Discretion, 86 J. CRIM. L. \& CRIMINOLOGY 717, 734 (1996); cf. BooK of THE STATEs, supra note 158, at 235 tbl.4.21 (listing the prosecutorial and advisory duties of the Attorney General with respect to local prosecutions).

159 Only three states do not elect their local prosecutors: Alaska, Delaware, and Rhode Island. Rasmusen et al., supra note 149, at 49, 68-69 (noting that, in 1994, U.S. state courts convicted 870,000 people of felonies, and the federal courts convicted another 44,000 ). In the three states that do not elect local prosecutors, the state Attorney General oversees criminal prosecution. See id. Even so, in two of these states-Rhode Island and Delaware-the Attorney General is still an elected official. See id.

$160 \mathrm{Id}$.

161 See infra Part III.B. 
sions the way federal attorneys general have done with the Bush Administration would very likely face significant challenges in her next election cycle. ${ }^{162}$ It is equally likely that the framers, whose goals were to check the power of any one branch of government, ${ }^{163}$ ensure responsiveness to the citizenry ${ }^{164}$ and allow for constitutional change when events merit, ${ }^{165}$ would not object to amending Article II to create a directly elected attorney general and thus ensure a more responsive and accountable Executive Branch.

\section{B. A Revived-and Revised-Independent Counsel}

1. History of the Independent Counsel

Quite unintentionally, President Richard Nixon provided the inspiration for the creation of an independent counsel to investigate and prosecute Executive Branch crimes. First, in 1971, President Nixon allegedly ordered Deputy Attorney General Richard Kleindienst to drop the government's antitrust suit against International Telephone and Telegraph Corp., which happened to be a major contributor to the 1972 Republican Convention. ${ }^{166}$ Then, on October 20,1973, Nixon carried out his infamous "Saturday Night Massacre," ordering Attorney General Elliot Richardson to fire Watergate special prosecutor Archibald Cox after the District Court for the District of Columbia ordered Nixon to turn over tape recordings that Cox had subpoenaed.167 Although both Richardson and his deputy, William Ruckelhaus, refused to obey Nixon's order and resigned, Solicitor General Robert Bork obeyed Nixon's order and fired Cox. ${ }^{168}$

162 See Gregory Huber \& Sanford Gordon, Citizen Oversight and the Electoral Incentives of Criminal Prosecutors, 46 AM. J. PoL. ScI. 334, 337 (2002) (noting that voters can observe and evaluate their prosecutor's performance, and candidates for these positions may advertise an incumbent's poor results).

163 See The Federalist No. 51, supra note 109, at 321-22 (James Madison).

164 See id. at No. 52, at 327 (James Madison) ("As it is essential to liberty that the government in general should have a common interest with the people, so it is particularly essential that the branch of it under consideration should have an immediate dependence on, and an intimate sympathy with, the people. Frequent elections are unquestionably the only policy by which this dependence and sympathy can be effectually secured.").

165 See U.S. Const. art. V ("The Congress, whenever two thirds of both Houses shall deem it necessary, shall propose Amendments to this Constitution, or, on the Application of the Legislatures of two thirds of the several States, shall call a Convention for proposing Amendments, which, in either Case, shall be valid to all Intents and Purposes, as part of this Constitution, when ratified by the Legislatures of three fourths of the several States, or by Conventions in three fourths thereof, as the one or the other Mode of Ratification may be proposed by the Congress .....").

166 The Nation: Re-Opening ITT, Time, Nov. 12, 1973, available at http://www.time.com/ time/magazine/article/0,9171,944655,00.html.

167 Carl Bernstein \& Bob Woodward, All the President's Men 333 (1974).

168 Id. 
President Nixon's brazen efforts to place himself above the law led to dozens of congressional proposals for reforming the investigation and prosecution of Executive Branch matters. ${ }^{169}$ Unsuccessful proposals included turning the Department of Justice into an independent agency headed by an attorney general appointed for a fixed six-year term ${ }^{170}$ and allowing the courts or Congress to directly appoint a special prosecutor to investigate acts of Executive Branch wrongdoing. ${ }^{171}$ Narrower but successful efforts included allowing the Comptroller General, whom the President appoints with the advice and consent of the Senate to a fifteenyear term, ${ }^{172}$ to obtain information from executive departments, investigate fraud in those departments, and sue to challenge executive impoundments. ${ }^{173}$

Ultimately, Nixon's overreach led to the passage of the 1978 Ethics in Government Act, which provided for the creation of an independent counsel. ${ }^{174}$ The Act required the Attorney General, upon learning of alleged criminal activity, to investigate high-ranking executive officials including the President, Vice President, cabinet-level officials, highranking officials in the Executive Office of the President and the Department of Justice, the Central Intelligence Agency, the Internal Revenue Service, and the President's national campaign. ${ }^{175}$ If the Attorney General found reasonable grounds for further investigation, she applied to the Special Division, a three-judge panel chosen by the Chief Justice of the Supreme Court, for the appointment of a special prosecutor or "independent counsel." 176 After referral of the matter to the Special Division, the Attorney General and the Department of Justice suspended their own investigations and proceedings and allowed the independent counsel to proceed with "all investigative and prosecutorial functions." 177 The At-

169 See Ken Gormley, An Original Model of the Independent Counsel Statute, $97 \mathrm{MicH}$ L. REv. 601, 608 (1998).

170 Removing Politics from the Administration of Justice: Hearing on S. 2803 and S. 2978 Before the Subcomm. on Separation of Powers of the S. Comm. on the Judiciary, 93d Cong. 229, 233-47, 250 (1974) [hereinafter Removing Politics from the Administration of Justice].

171 Id.

17231 U.S.C. $\$ 703$ (2006).

173 See, e.g., Impoundment Control Act of 1974, Pub. L. No. 93-344, § 10, 88 Stat. 297, 332 (codified as amended at 2 U.S.C. $\$ 687$ (Supp. V 1987)) (authorizing the Comptroller General to sue to challenge executive impoundments); General Accounting Office Act of 1980, Pub. L. No. 96-226, 94 Stat. 311 (1980) (authorizing the Comptroller General to sue to obtain information from executive departments); Inspector General Act of 1978, Pub. L. No. 95-452, 92 Stat. 1101 (1978) (authorizing the Inspector General to investigate waste and fraud in executive agencies), amended by Balanced Budget and Emergency Deficit Control Reaffirmation Act of 1987, Pub. L. No. 100-119, 101 Stat. 754, 786 (1987).

174 Ethics in Government Act of 1978, Pub. L. No. 95-521, § 6, 92 Stat. 1824, 1867-73

(1978) (codified as amended at 28 U.S.C. $\$ \S 591-99$ (1994)) (repealed 1999).

175 See id. $\$ 592$.

176 See id. $\S \S 592-93$.

177 Id. $§ 594$. 
torney General retained the ability to remove the independent counsel for incapacity or extraordinary impropriety, and either the independent counsel or the Special Division could terminate the office. ${ }^{178}$ The Ethics in Government Act included a five-year sunset provision ${ }^{179}$ and was subsequently renewed three times, with some amendments, and renamed the Independent Counsel Act. ${ }^{180}$

In 1988, the U.S. Supreme Court upheld the constitutionality of the Independent Counsel Act in Morrison v. Olson. ${ }^{181}$ Based on the conclusion that the independent counsel was an "inferior," court-appointed officer, the Court first held that the Act did not violate the Appointments Clause of the Constitution, ${ }^{182}$ which vests major appointment powers in the President. ${ }^{183}$ The Court then found that no separation of powers concerns existed because the Attorney General and the President retained the power to make the initial referral of the matter to the Special Division and to remove the independent counsel for good cause. ${ }^{184}$

Despite the Supreme Court's imprimatur, delivered in a 7-1 majority decision over Justice Scalia's dissent, the independent counsel received widespread criticism from conservative legal scholars who found the legislation to be both unnecessary and a violation of the separation of powers. ${ }^{185}$ In the 1990s, these scholars gained allies across the ideological spectrum after former D.C. Circuit Court of Appeals Judge Kenneth W. Starr's wide-ranging, five-year investigation of the Clinton Administration. ${ }^{186}$ Starr's investigation strayed far from its original mandate by moving from alleged improprieties in the Clintons' pre-presidential real

178 See id. $\S 596$.

179 See id. \$ 599.

180 See Katy J. Harriger, The History of the Independent Counsel Provisions: How the Past Informs the Current Debate, 49 MerCer L. Rev. 489, 505-14 (1998).

181487 U.S. 654, 659-69 (1988).

182 U.S. Const. art. II, $\S 2$, cl. 2; Morrison, 487 U.S. at 672.

183 U.S. Const. art. II, $\S 2$, cl. 2 ("[The President] shall nominate, and by and with the Advice and Consent of the Senate, shall appoint Ambassadors, other public Ministers and Consuls, Judges of the supreme Court, and all other Officers of the United States, whose Appointments are not herein otherwise provided for, and which shall be established by Law: but Congress may by Law vest the Appointment of such inferior Officers, as they think proper, in the President alone, in the Courts of Law, or in the Heads of Departments.").

184 Morrison, 487 U.S. at 695 ("The Act does give the Attorney General several means of supervising or controlling the prosecutorial powers that may be wielded by an independent counsel. .. . Notwithstanding the fact that the counsel is to some degree "independent" and free from executive supervision to a greater extent than other federal prosecutors, in our view these features of the Act give the Executive Branch sufficient control over the independent counsel to ensure that the President is able to perform his constitutionally assigned duties.").

185 See, e.g., Carter, supra note 52; Michael B. Rappaport, Replacing Independent Coun. sels with Congressional Investigations, 148 U. PA. L. REv. 1595, 1604 (2000).

186 See David Halperin, Ethics Breakthrough or Ethics Breakdown? Kenneth Starr's Dual Roles as Private Practitioner and Public Prosecutor, 15 Geo. J. Legal ETHIcs 231, 242-43 (2002) (calling the scope of Starr's investigation as approved by the Special Division "an extraordinary expansion of his jurisdiction"). 
estate dealings in Arkansas to investigations into the firings of White House travel office staff, allegations of illegal foreign campaign contributions, and finally to the President's extramarital affair with White House intern, Monica Lewinsky. ${ }^{187}$ The Starr investigation was widely criticized as partisan in motivation, ${ }^{188}$ and when Starr and the Special Division proved to be impervious to that criticism, critics focused on the lack of accountability in the independent counsel scheme. ${ }^{189}$ Popular and congressional concerns over the Starr investigation doomed the Independent Counsel Act, and Congress allowed it to sunset in 1999. ${ }^{190}$

\section{The Special Counsel}

With the Independent Counsel gone, the Department of Justice issued new regulations to create a special counsel to investigate allegations of wrongdoing in the Executive Branch. ${ }^{191}$ Although the stated goals of the special counsel provision sounded similar to the independent counsel legislation-it required separation from the ordinary prosecution review if the investigation "would present a conflict of interest for the Department [of Justice]" and "would be in the public interest"192 - the removal of the adjective "independent" from any designation of this position is significant. ${ }^{193}$ This removal is more than semantic: in fact, the Attorney General controls the special counsel from start to finish, as she retains the power to determine (1) whether to appoint the Special Counsel, ${ }^{194}$ (2) who to select, ${ }^{195}$ (3) what the Counsel's jurisdiction will be, ${ }^{196}$ and (4)

187 See id.

188 See, e.g., Editorial, Mr. Starr's Conflicts, N.Y. TIMEs, Mar. 31, 1996, http:// www.nytimes.com/1996/03/31/opinion/mr-starr-s-conflicts.html.

189 See Cass R. Sunstein, Bad Incentives and Bad Institutions, 86 Geo. L.J. 2267, 2274 (1998); see also Erwin Chemerinsky, Learning the Wrong Lessons from History: Why There Must Be an Independent Counsel Law, 5 WIDENER L. SYMP. J. 1, 2 (2000) ("After the Whitewater debacle, the idea of an independent counsel seems clearly doomed. Many Republicans have always opposed the law because of its anti-Nixon origins and because of its use against Republican presidents, such as in the Iran-Contra scandal. Now Democrats have equal reason to hate the independent counsel statute because of how it was used against the Clinton Administration.").

190 See id.; see also Halperin, supra note 186, at 235. Halperin explains that the decision to allow the Independent Counsel Act to sunset reflected the "collective judgment" of President Clinton, his Administration, Congress, and a considerable number of "scholars, journalists, and other observers." Halperin, supra note 186, at 235 . Essentially, "the benefits gained in avoiding abuses and conflicts of interest by means of the independent counsel law were outweighed by negative consequences of the law: the potential for abuses of power by independent counsels themselves, excessive expenditure of resources, and undue burdens on innocent officials." Id.

191 See Office of Special Counsel Regulations, 28 C.F.R. $\$ 600$ (2009).

192 Id. $\S 600.1$.

193 Id.

194 Id. $\$ 600.2$.

195 Id. $\$ 600.3$.

196 Id. $\$ 600.4$. 
whether to suspend the investigation at any time with only the proviso that the Attorney General notify Congress of the suspension decision. ${ }^{197}$ In short, the independent counsel statute returns to the Attorney General all of the roles formerly invested in the Special Division. ${ }^{198}$

\section{Envisioning a Revived and Redesigned Independent Counsel}

Given the lack of an independent permanent prosecutor, the absence of an independent counsel statute, and the toothlessness of the special counsel structure, it is not surprising that the Bush Administration sanctioned torture with the confidence that comes with self-provided impunity. ${ }^{199}$ This disturbing turn of events suggests that Congress overreacted to the abuse of the independent counsel statute in the 1990s, in essence throwing the independent prosecutor baby out with the Starr investigations bathwater. ${ }^{200}$ The sprawl of the Starr investigation in the face of public disapproval exposed a fundamental flaw of the Independent Counsel Act: neither the independent counsel nor its appointing body, the Special Division, was accountable to the electorate. ${ }^{201}$ Scholars proposed two structural changes after Watergate that could guide the redesign. One proposal would make the Department of Justice an independent agency, like the Federal Trade Commission, ${ }^{202}$ with an attorney

197 Id. $\S 600.7(\mathrm{~b})$.

198 See John Padilla \& Alex Wagner, The "Outing" of Valerie Plame: Conflicts of Interest in Political Investigations After the Independent Counsel Act's Demise, 17 GEo. J. LegaL ETHICs 977, 987 (2004) (discussing parallels between the Independent Counsel Act and special counsel provisions).

199 See Bradbury Memorandum, in Torture Memos, supra note 18, at 273 (showing the Deputy Attorney General's assurance to the Executive Branch that judicial scrutiny of torture decisions was extremely unlikely).

200 See Chemerinsky, supra note 189, at 2 ("The lessons to be learned from the abuses of the Whitewater special counsel should be about how to reform the law, not why to end it.").

201 See David A. Strauss, The Independent Counsel Statute: What Went Wrong?, 51 ADMIN. L. REv. 651, 652 (1999) ("You simply cannot have a criminal prosecutor, with so much power, subject to such limited checks."); see also Rappaport, supra note 185, at 1600-01 ("[One] problem is that independent counsels exercise significant discretion but are not accountable to the electorate. Independent counsels perform important duties that involve a substantial amount of policymaking discretion, including deciding whether certain conduct by an official warrants an indictment. In a democracy, persons who exercise such discretion are generally made accountable to the public. . . . Independent counsels, however, have virtually no accountability because they are appointed by judges, take orders from no one, and can be removed only for cause. . . . The Independent Counsel's lack of accountability is not merely a problem of democratic theory, but also of democratic practice. Because the Independent Counsel is unconstrained by the fundamental democratic check on policymaking - having to stand for election-there is a significant danger that she will behave unreasonably. The Independent Counsel's lack of accountability also deprives her of the political legitimacy that is crucial to the performance of her duties.").

202 Removing Politics from the Administration of Justice, supra note 170; see also Brett M. Kavanaugh, The President and the Independent Counsel, 86 GEo. L.J. 2133, 2145-49 (1998) (suggesting that the President appoint the independent counsel subject to Senate confirmation). 
general appointed by the President or Congress for a fixed term of years. ${ }^{203}$ An alternative proposal calls for congressional appointment of a special prosecutor with the exclusive purpose to investigate allegations of criminal behavior in the Executive Branch. ${ }^{204}$ In either system, the appointing body would be directly responsible to the electorate in a way the Special Division, which allowed Starr to run amuck, was not. ${ }^{205}$

To have a truly "independent" counsel, an improved system must not grant the Attorney General and the President the power to appoint and remove the prosecutor or define her jurisdiction. The Attorney General's power in these areas undermined the independence of the prosecution under the Independent Counsel Act. Misuse of this power is easy to imagine when considering the Bush Administration's refusal to follow torture laws or cooperate with legislative and judicial attempts to regulate its practices. The President could simply instruct the Attorney General to refuse to initiate appointment of independent counsel even in the face of calls for one by less self-interested observers. ${ }^{206}$ Indeed, for President Clinton, the take-home lesson from the Starr investigations was not that the independent counsel overstepped his bounds, but that Clinton should have never allowed his Attorney General to request an independent counsel in the first place. ${ }^{207}$

While this may be a legitimate lesson to take from the Starr era if one is interested chiefly in the friction-free exercise of presidential power, the reality of presidential inaction to remedy executive abuses is

203 See Removing Politics from the Administration of Justice, supra note 170.

204 See id. This proposal bears a resemblance to Michael Rappaport's later suggestion to endow a new congressional investigative committee with additional subpoena powers and equip it with a professional investigative staff to review and expose Executive Branch misconduct. See Rappaport, supra note 185, at 1586; infra note 207 and accompanying text.

205 A practical challenge to legislation that removes the Executive Branch entirely from the independent counsel appointment and review process is that the Supreme Court cited these very oversight provisions as justification for upholding the constitutionality of the Independent Counsel Act in Morrison. See Morrison v. Olson, 487 U.S. 654, 695 (1988). Even though it appears that the framers intended the Attorney General to be a weak office and did not envision a great deal of presidential control over federal prosecution, the Morrison reasoning would argue for an executive-appointed, fixed-term attorney general over a congressionallyappointed prosecutor. See id. at 694; supra notes 113-18; see also Free Enterprise Fund v. Public Company Accounting Oversight Board, 130 S. Ct. 3138 (2009) (distinguishing Morrison and Humphrey's Executor v. United States, 295 U.S. 602 (1935) in finding that the Sarbanes-Oxley Act's creation of a Public Company Accounting Oversight Board contradicts Article II's vesting of the executive power in the President by conferring executive power on Board members without subjecting them to Presidential control).

206 See Chemerinsky, supra note 189 , at 6.

207 See Taylor Branch, The Clinton Tapes: Wrestling History with the PresiDENT 428 (2009) (paraphrasing Clinton as saying that he "had been a fool to establish the Whitewater special prosecutor"); see also BoB Woodward, The Cholce: How Clinton Won 444 (2005) (quoting Clinton as telling 1996 election opponent, Sen. Bob Dole, who had opposed reauthorization of the Independent Counsel Act, "You were right and I was wrong on the independent counsel."). 
anathema to a government built on a system of checks and balances. Though the Starr investigations showed that a truly independent counsel can lead to plenty of friction and inefficiencies in Executive Branch activities, the country's founders sought to create such structural impediments to the ambitions of any one branch of government. ${ }^{208}$ Reacting to the Starr investigation's flaws by removing independent prosecutorial oversight of the Executive Branch was shortsighted. The better solution is for Congress to revive and redesign the independent counsel structure.

\section{Breaking up the Prosecutorial Monopoly: Alternatives for Pursuing Executive Branch Misconduct}

An alternative to removing the prosecutorial power over the federal Executive Branch from the President-controlled Attorney General is to introduce competition to the heretofore monopoly power to pursue and punish Executive Branch members misdeeds. Economists would expect such competition to lead to a higher number of prosecutions of Executive Branch members and decrease the incentives for Executive Branch leaders to influence the dominant method of prosecution. ${ }^{209}$ Four alternatives for breaking up the current prosecutorial monopoly will be considered briefly here: (i) increasing the capacity of victims to punish Executive Branch misconduct, (ii) pursuing ethical complaints against Attorneys General and their attorney staff who show favoritism toward possible prosecution targets, (iii) bolstering the power of congressional or internal government investigations, and (iv) initiating criminal charges against Executive Branch leaders by international or independent local prosecutors.

\section{Victim-Initiated Actions Against Executive Branch Officials}

Several alleged victims of Bush Administration-sanctioned torture have sought justice in the civil arena but have not yet prevailed on the merits of their claims. For example, Maher Arar, a Syrian-born Canadian citizen, brought suit against former Attorney General John Ashcroft, FBI Director Robert Mueller, former Secretary of Homeland Security Tom Ridge, and various U.S. immigration officials for participation in his "rendition" to Syria where he was interrogated, tortured, and ultimately released without charges. ${ }^{210}$ The Eastern District of New York dismissed Arar's suit alleging violations of the Torture Victims Protec-

208 See The Federalist No. 51, supra note 109, at 321-22 (James Madison) ("Ambition must be made to counteract ambition."); see also Chemerinsky, supra note 189, at 2 ("This tension between independence and accountability is not unique to the debate over the independent counsel law. Quite the contrary, it is at the core of countless constitutional issues.").

209 See van Aaken et al., supra note 131, at 9.

210 Arar v. Ashcroft, 585 F.3d 559, 563 (2d Cir. 2009). 
tion Act, the Fifth Amendment, and international law. 211 The Second Circuit, sitting en banc, upheld the dismissal in late 2009 by ruling that there was no cognizable civil remedy for a victim of rendition. ${ }^{212}$ Another torture litigant still awaits resolution of his suit: Jose Padilla, held under the designation of "enemy combatant" in solitary confinement for more than three years in Charleston, S.C., sued Bush Department of Justice official and torture memoranda author, John Yoo, for actions that Padilla claims led to his torture. ${ }^{213}$ In 2009, the Northern District Court of California rejected Yoo's claim of qualified immunity and allowed Padilla's suit to go forward.214

Even if these or other suits succeed in obtaining significant civil remedies against Executive Branch officials, they are best viewed as a supplement to, rather than a replacement for, criminal prosecution. Those who remember the images of high-profile defendant O.J. Simpson smiling on the golf course or cavorting in Las Vegas after being found civilly liable, but criminally acquitted, for two deaths ${ }^{215}$ can attest to the significant gap in punitive impact between civil and criminal liability. ${ }^{216}$ In the context of torture, the CIA Inspector General reported that the agents involved in the torture of detainees were extremely concerned about the potential for criminal prosecution of their activities. ${ }^{217} \mathrm{Al}-$ though that concern did not prevent torture from occurring, it is certainly possible the activities would have been more brutal but for the fear of

211 See Arar v. Ashcroft, 414 F. Supp. 250, 287-88 (E.D.N.Y. 2006).

212 See id. at $580-81$.

213 Padilla v. Yoo, 633 F. Supp. 2d 1005, 1012-14 (N.D. Cal. 2009).

214 See id. at 1038. A torture-related case that does not name government officials as defendants is Mohamed v. Jeppesen Dataplan, Inc., 563 F.3d 992 (9th Cir. 2009) amended and superseded by 579 F.3d 943 (9th Cir. 2009). In Jeppesen Dataplan, five foreign nationalswho allegedly had been transferred in secret to foreign countries for detention and interrogation pursuant to the "extraordinary rendition" program operated by Central Intelligence Agency-sued under the Alien Tort Statute, 28 U.S.C. § 1350, against Jeppesen, a Boeing subsidiary company alleged to have taken part in the program. See Jeppesen Dataplan, 563 F.3d at 997. Before Jeppesen filed an answer to the complaint, the United States intervened, asserting that the state secrets privilege required dismissal of the entire action on the pleadings. Id. The U.S. Court of Appeals for the Ninth Circuit reversed the trial court dismissal of the complaint. See id.

215 See generally Brown v. Simpson, No. SC036876 (Cal. Super. Ct. Feb. 10, 1997), available at http://www.lasuperiorcourt.org/civil (follow "case summary" hyperlink and enter "SC036876" into the appropriate search field) (providing basic procedural information about the case); Goldman v. Simpson, No. SC036340 (Cal. Super. Ct. Aug. 1, 1995), available at http://www.lasuperiorcourt.org/civil (follow "case summary" hyperlink and enter "SC036340" into the appropriate search field) (providing basic procedural information about the case) (same basic information provided); see also JefFery ToOBIN, The Run of His Life: The People v. O.J. Simpson 444-58 (1997) (discussing the civil charges filed against Simpson).

216 Simpson was subsequently convicted and imprisoned for armed robbery in Nevada. See O.J. Simpson Sentenced to Long Prison Term, MSNBC.сом, Dec. 5, 2008, http:// www.msnbc.msn.com/id/28067187/.

217 CIA OIG REP., supra note 4, at 94, 101. 
criminal sanctions, or that the torture would have been significantly reduced or even absent if the Department of Justice had not issued approving legal opinions in advance. ${ }^{218}$

Beyond the deterrence aspect of potential prosecution for official misconduct, ${ }^{219}$ the larger question remains: In a system where no person is supposed to be above the law, why should Executive Branch leaders be subject to mere civil liability for acts that would likely result in imprisonment for others? Precedent does in fact exist for allowing victims of crimes to transcend the limitations of a civil remedy by pursuing criminal charges. At the time of the founding of the United States, several states still followed the English tradition of allowing private citizens to initiate criminal prosecutions. ${ }^{220}$ While victim-initiated prosecution is not allowed in the United States today, in some European systems, victims may file and pursue criminal charges. ${ }^{221}$ In Spain, even non-victims can lead a criminal prosecution. ${ }^{222}$ Allowing public interest groups to file and pursue criminal charges may be ideal in the context of official misconduct, as the harm caused is more likely to be widespread and generalized.223

\section{Pursuit of Ethical Complaints Against Attorneys General and Department of Justice Officials}

Bringing ethical charges against federal officials provides another avenue to police Executive Branch abuses. Because the Attorney General and high-level members of the Department of Justice practice law in the nation's capital, they are subject to the Washington, D.C. Rules of Professional Conduct. ${ }^{224}$ Failure to prosecute Executive Branch officials for misconduct because of political ties may run afoul of Washington

218 See, e.g., Harold G. Gramsick \& Robert J. Bursik, Conscience, Significant Others, and Rational Choices: Extending the Deterrence Model, 24 LAw \& Soc'y REv. 837, 839-40 (1990) (citing research showing that potential sanctions have no deterrent effect if the rational actor perceives little or no probability of punishment being imposed.).

219 See van Aaken et al., supra note 131.

220 See S. Milsom, Historical Foundations of the Common Law 404 (2d ed. 1981); Andrew D. Leipold, Why Grand Juries Do Not (and Cannot) Protect the Accused, 80 CoRNELI L. REv. 260, 283 (1995).

221 See Marion E. Brienen \& Ernestine H. Hoegen, Victims of Crime in 22 European Criminal Justice Systems 1064-65 (2000).

222 Id.

223 See van Aaken et al., supra note 131, at 9.

224 See, e.g., ABA Standards for Criminal Justice: Prosecution and Defense FuncTION STD. 3-1.2 (3d ed., 1993), available at http://www.abanet.org/crimjust/standards/prosecutionfunction.pdf; $c f$. Kathleen Clark, Ethical Issues Raised by the OLC Torture Memorandum, 1 J. NAT'L SECuRITY L. \& PoL'y 455, 464 (2005) [hereinafter Clark, Ethical Issues] (noting that Jay Bybee and John Yoo were subject to the Washington, D.C. Rules of Professional Conduct at the time they authored the "Torture Memos"); Marc Stepper, Note, A Government Lawyer's Liability Under Bivens, 20 CORNELl J.L. \& PUB. POL'y (forthcoming Feb. 2011) (noting that actors like Yoo, who was characterized by one court as the "de facto head of war- 
D.C. Rules of Professional Conduct 3.8 which states, "The prosecutor in a criminal case shall not: (a) In exercising discretion to investigate or to prosecute, improperly favor or invidiously discriminate against any persons." 225 Thus, federal attorneys who drag their heels in prosecuting the Executive Branch should be subject to discipline for violation of the professional ethics rules. ${ }^{226}$

The Office of Professional Responsibility (OPR), an internal ethics unit within the Justice Department, may assist in Executive Branch disciplinary measures as well. In the wake of the revelation of Bush Administration torture activities, some have called for disciplinary actions against former Department of Justice officials and torture memoranda authors John Yoo, now a law professor at University of California Berkeley, and Jay Bybee, now a federal judge in Nevada..227 A pending opinion by the OPR reportedly includes a referral to state bar associations to consider possible actions against Yoo and Bybee.228

Unfortunately, the pursuit of ethical charges against an Attorney General or top Justice Department official, like bringing civil claims, is a legitimate but insufficient response to Executive Branch misconduct. Such ethical charges against attorney torture enablers are certainly justified and may well inspire future government attorneys to hold themselves to a higher standard of behavior. However, professional ethics complaints alone do not address the need to hold Executive Branch officials to the same level of impartial prosecutorial oversight as other citizens who are subject to criminal sanctions for violations of clear legal mandates.

\section{Greater Investigative Power for Congress or an Inspector General}

To remedy the conflict of interest present in Executive Branch prosecution, some scholars have called for oversight by other government officials. Professor Michael Rappaport has suggested creating a new

on-terrorism legal issues," often see their recommendations implemented directly into executive policy).

225 District of Columbia Rules of Prof'L Conduct R. 3.8(a) (2007), available at http://www.dcbar.org/for_lawyers/ethics/legal_ethics/rules_of_professional_conduct/ amended_rules/rule_three/rule03_08.cfm.

226 See Viggiano, supra note 38, at 1200-01.

227 Clark, Ethical Issues, supra note 224, at 464; see also BuelahMan, National Lawyer's Guild Says John Yoo Is a War Criminal, BuelahMan's Revolt Blog (Apr. 9, 2008), http:// buelahman.wordpress.com/2008/04/09/national-lawyers-guild-says-john-yoo-is-a-war-criminal/ (reposting Press Release, National Lawyers Guild Calls On Boalt Hall To Dismiss Law Professor John Yoo, Whose Torture Memos Led to Commission of War Crimes (Apr. 9, 2008)).

228 David Johnston \& Scott Shane, Torture Memos: Inquiry Suggests No Prosecutions, N.Y. Times, May 6, 2009, at A1. 
congressional investigative committee with additional subpoena powers and a professional investigative staff to review and expose Executive Branch misconduct.229 Professor Kathleen Clark has proposed establishing a permanent inspector general within the White House empowered to investigate Executive Branch wrongdoing and report to Congress. ${ }^{230}$ Both proposals have their strengths: Rappaport's proposal would make the investigative body more accountable to the electorate, ${ }^{231}$ thus remedying a major flaw of the Independent Counsel Act, and Clark's proposal would place a quasi-independent investigator on the scene of the Executive Branch activities. ${ }^{232}$ Neither solution, however, goes far enough towards holding executive officials truly accountable, because they do not allow for prosecution of criminal acts. This prosecution is an essential component of a system promising that no person, not even the President, is above the law.

\section{Non-federal Prosecution of Executive Branch Crimes}

Domestic and international actors, frustrated with the lack of U.S. investigation and prosecution of Bush Administration misdeeds, have looked to international courts. ${ }^{233}$ To date, this strategy has produced limited, positive results. In 2009, Baltasar Garzon, a Spanish judge known for his prosecutions of alleged international human rights abusers such as Chilean dictator Augusto Pinochet, ${ }^{234}$ launched a criminal investigation of Bush Administration officials for torture by citing the Geneva Conventions and the 1984 Convention Against Torture as the legal basis for the investigation. ${ }^{235}$ In 2006, the Center for Constitutional Rights, a U.S.-based human rights organization, and other organizations requested that a German judge issue an indictment against Bush Administration

229 See Rappaport, supra note 185, at 1595-97.

230 See Kathleen Clark, Toward More Ethical Government: An Inspector General for the White House, 49 MERCER L. Rev. 553, 560-61 (1998) [hereinafter Clark, Ethical Government].

231 See Rappaport, supra note 185, at 1597.

232 See Clark, Ethical Government, supra note 230, at 564.

233 Such international prosecution may be the result of U.S. efforts to immunize tortureimplicated officials from domestic prosecution. See Sands, supra note 24, at 370 (internal cross-reference omitted) (quoting a European prosecutor as saying it was "very stupid" of the United States to attempt to provide immunity in the Military Commissions Act of 2006, as this provides a justification for foreign prosecutors to pursue charges in their own jurisdictions).

234 See Clifford Krauss, Britain Arrests Pinochet to Face Charges by Spain, N.Y. Times, Oct. 18, 1998, http:/www.nytimes.com/1997/03/26/world/argentine-ex-leader-s-arrest-issought.html?ref=baltasar_garzon.

235 Marlise Simons, Spanish Court Weighs Inquiry on Torture for 6 Bush-Era Officials, N.Y. Times, Mar. 29, 2009, http://www.nytimes.com/2009/03/29/world/europe/29spain.html. 
officials for similar crimes, ${ }^{236}$ but that request was denied. ${ }^{237}$ In 2009, an Italian judge convicted in absentia twenty-three Americans, mostly CIA operatives, of kidnapping a Muslim cleric from the streets of Milan and transporting him to Egypt where the cleric claims he was interrogated and tortured as part of the U.S. practice of rendition. ${ }^{238}$ Although such cases garner international attention and may have received a boost from U.S. efforts to provide immunity for torturers, ${ }^{239}$ it is unclear whether any of these actual or possible prosecutions will result in the imposition of prison sentences or other penalties. ${ }^{240}$

To date, the protection that U.S. Executive Branch officials enjoy in the international arena has been replicated at the local level due to the uniquely non-local nature of prosecution in Washington, D.C. If an Executive Branch leader were to commit a criminal act in Maryland, Virginia, Indianapolis, or Indiana, a locally-elected prosecuting attorney would likely prosecute the crime. ${ }^{241}$ But that is not the case in the District of Columbia where the U.S. Attorney's office, ultimately accountable to the President, prosecutes felony crimes under the D.C. Code. ${ }^{242}$ Thus, although the D.C. Code contains provisions that could apply to Executive Branch official misconduct including obstruction of justice ${ }^{243}$ and bribery, ${ }^{244}$ the same conflicts of interest inherent in federal prosecution make pursuing those charges at the local level quite unlikely.

However, District of Columbia officials ${ }^{245}$ and legal scholars ${ }^{246}$ have argued that the responsibility for local criminal prosecution be

236 Mark Landler, Rumsfeld Faces War Crimes Suit in Germany, INT'L HER. TRIB., Nov. 14, 2006, http://www.nytimes.com/2006/11/14/world/americas/14iht-rumsfeld.3532840.html.

237 Oberlandesgericht Stuttgart [Higher Regional Court of Stuttgart], Apr. 21, 2009, at 3 (Ger.), available at http://ccrjustice.org/files/Beschluss\%200LG\%20Stuttgart.pdf. For a list of documents submitted in that case, see German War Crimes Complaint Against Donald Rumsfeld et al., CENTER FOR CONST. RTs., http://ccrjustice.org/ourcases/current-cases/germanwar-crimes-complaint-against-donald-rumsfeld-et-al (last visited Oct. 25, 2010).

238 See, e.g., Rachel Donadio, Italy Convicts 23 Americans, Most Working for CIA, of Abducting Muslim Cleric, N.Y. Times, Nov. 4, 2009, at A14-15.

239 See, e.g., Charlie Savage, Court Dismisses A Case Asserting Torture by C.I.A., N.Y. Times, Sep. 9, 2010 at Al (noting that the Obama Administration successfully argued that prisoners of the CIA could not sue over the alleged torture in overseas prisons because such a lawsuit might expose secret government information).

240 See Sands, supra note 24, at 370-71.

241 See Rasmusen et al., supra note 149, at 49.

242 D.C. CoDE $\$ 23-101$ (c) (2001).

243 Id. $\$ 22-722$.

244 Id. \$ 22-713.

245 See PR 12-671, Sense of the Council. Regarding the Establishment of an OfFice of the Attorney General of the District of Columbia Resolution of 1998, available at DC Watch Archives, DC WATCH, http://www.dcwatch.com/archives/council12/12671.htm.

246 See John Payton, Should the District of Columbia Have Responsibility for the Prosecution of Criminal Offenses Arising Under the District of Columbia Code?, 11 U. D.C. L. REv. 35,37 (2008) ("Democracy supplies an important check on the exercise of a prosecutor's 
placed with a District of Columbia governmental entity. Eleanor Holmes Norton, the Congresswoman representing the District of Columbia, has introduced legislation to establish an Office of District Attorney for the District of Columbia to be headed by a locally elected district attorney. ${ }^{247}$ This bill has both the philosophical advantage of being aligned with the framers' preference for local law enforcement over federal police and prosecution ${ }^{248}$ and the more tangible advantage of being aligned with statements made by President Obama, a co-sponsor of the District of Columbia Voting Rights Act of 2007 that was designed to provide the District with greater self-rule. ${ }^{249}$ Should the Voting Rights Act become law, it would bust the federal monopoly over prosecution of executive officials and align Washington with the fifty states of the union where local prosecution is more the rule than the exception.

\section{CONCLUSION}

Due to a conflict of interest as blatant as the proverbial fox guarding the henhouse, two consecutive Presidents and their attorneys general have declined to investigate or prosecute Executive Branch activities sanctioning torture. If the United States is to live up to its aspiration to be a government of laws and not men, this structural flaw must be remedied. The direct election of an attorney general is the most precise and effective remedy for this flaw. But the revival and improvement of the independent counsel, or else the enactment of provisions to break up the current monopoly over Executive Branch prosecution, are also vastly preferable to leaving in place a system that flouts the principles of equal justice and ignores checks on individual power.

discretion. Democracy helps ensure that the criminal laws reflect the concerns and values of the community. This democratic accountability of the prosecutorial function is not present in the District.").

247 District of Columbia District Attorney Establishment Act of 2007, H.R. 1296, 110th Cong. $\S 2$ (a) (2007), available at http://frwebgate.access.gpo.gov/cgi-bin/getdoc.cgi?dbname= 110_cong_bills\&docid=f:h1296ih.txt.pdf.

248 See Bloch, supra note 112 , at 568.

249 District of Columbia House Voting Rights Act of 2007, S. 1257, 110th Cong. (2007), available at http://thomas.loc.gov/cgi-bin/bdquery/z?d110:SN01257:@@@P; see also Justin Ewers, D.C. Voting Rights Supporters Have Best Shot Yet with Obama in the White House, U.S. News \& WORLd ReP., Jan. 8, 2009, http:/www.usnews.com/articles/news/politics/2009/ 01/08/dc-voting-rights-supporters-have-best-shot-yet-with-obama-in-the-white-house.html. The House of Representatives passed the Act in 2007 and the Senate passed it in 2009. See Dem: No Vote on D.C. Voting Rights Act this Year, MSNBC.COM, Apr. 20, 2010, http:// www.msnbc.msn.com/id/36665822/. However, the Senate version contained an amendment regarding the District's gun control laws, and so was sent back to the House of Representatives. See id. 
